\title{
THE NOMINAL SHARE PRICE PUZZLE
}

\author{
A Dissertation \\ Presented to the Faculty of the Graduate School \\ of Cornell University
}

In Partial Fulfillment of the Requirements for the Degree of

Doctor of Philosophy

by

William Charles Weld

May 2012 
(C) 2012 William Charles Weld 


\title{
THE NOMINAL SHARE PRICE PUZZLE
}

\author{
William Charles Weld, Ph. D.
}

Cornell University 2012

The average nominal prices of common stocks traded on the New York Stock Exchange have remained constant at approximately $\$ 30-\$ 40$ per share since the Great Depression as a result of stock splits. It is surprising that U. S. firms actively maintained constant nominal prices for their shares while general prices in the economy went up more than tenfold. This is especially puzzling given that commissions paid by investors on trading ten $\$ 30$ shares are about ten times those paid on a single $\$ 300$ share. I review potential explanations including signaling and optimal trading ranges and find that none of the existing theories are able to explain the observed constant nominal prices. I suggest that the evidence is consistent with the idea that customs and norms can explain the nominal price puzzle. 


\section{BIOGRAPHICAL SKETCH}

William Weld graduated from Harvard College, Cambridge, Massachusetts with an $\mathrm{AB}$ in Government in 1994, and from the Johnson Graduate School of Management, Cornell University with an MBA in 2001. He lives with his wife, two daughters, and two dogs in Chapel Hill, North Carolina. 


\section{DEDICATION}

Dedicated to Jen, Alexandra and Caroline.

Vulneratus Non Victus 


\section{ACKNOWLEDGMENTS}

I gratefully acknowledge my committee: Roni Michaely, Yaniv Grinstein, Mark Leary, and Hazem Daouk have all provided direction and insights that greatly improved my thinking and this work.

I recognize the University of Wisconsin-Madison School of Business, the University of North Carolina Chapel Hill's Kenan-Flagler School of Business, and their respective faculties for their support and understanding as I finished my dissertation. I am indebted to my coauthors Roni Michaely, Richard Thaler, and Schlomo Benartzi, as well as George Akerlof, Markus Brunnermeier, Henrik Cronqvist, Eugene Fama, Owen Lamont, Toby Moskowitz, Lubos Pastor, Avi Vohl, Jeffery Wurgler, and seminar participants at the 2007 NBER Behavioral Economics Working Group, 2007 AFA meeting, Cornell University, the University of Chicago, IDC, the University of Miami, the University of Utah, and the School of Management, Binghamton University.

Many friends have provided empathetic support that helped me write this essay. Roni Michaely again merits a special acknowledgment here. Bin Zhao, Prasun Agarwal, Lynn G., Lauri F., Ritu B., Kodiak B., and Millennium J. all deserve special thanks. Most importantly, I thank my family. Without them, I am nothing. The usual disclaimer applies: credit is to be shared by all, shortcomings are uniquely mine. 


\section{TABLE OF CONTENTS}

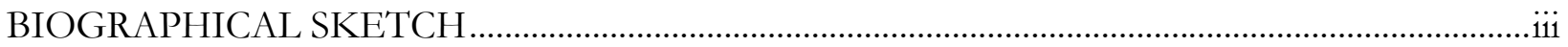

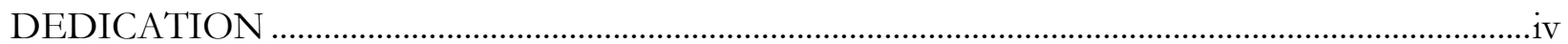

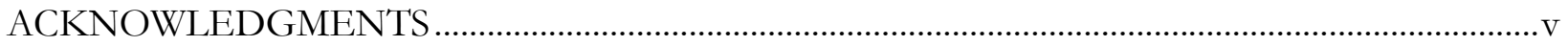

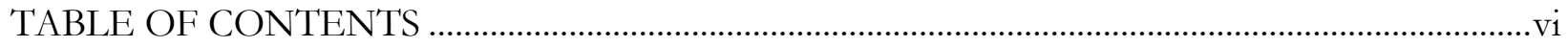

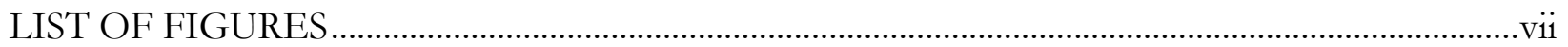

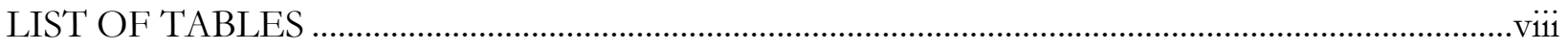

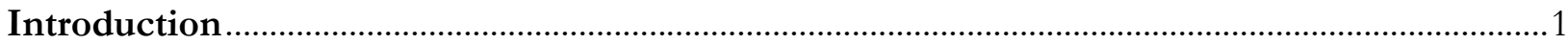

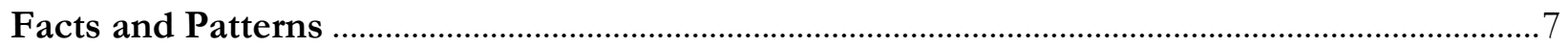

1. U.S. share prices have remained constant since the Great Depression........................................................

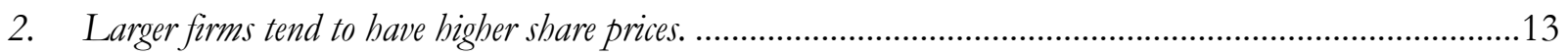

3. Initial public offering share prices have remained constant. .....................................................................15

4. Share prices of open-end mutual funds have remained roughly constant since the 1960 s.............................18

5. The pattern of share prices varies dramatically across countries..............................................................20

6. Maintaining constant prices increases trading costs ................................................................................28

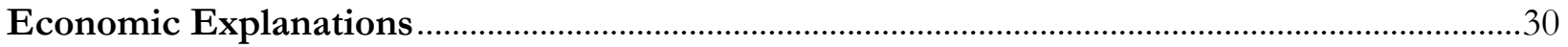

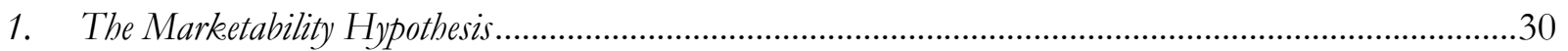

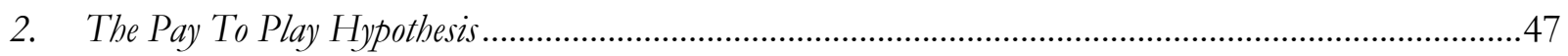

3. The Signaling Hypothesis .................................................................................................................

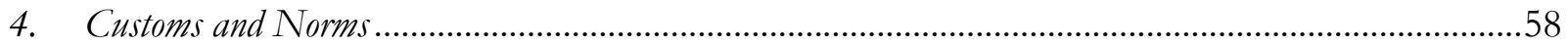

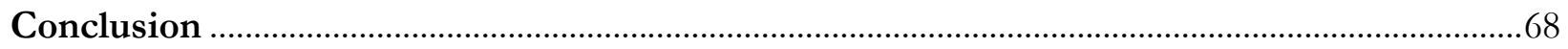

BIBLIOGRAPHY 


\section{LIST OF FIGURES}

Figure 1: Average Prices of Securities on the NYSE and AMEX, 1933 to 2007 ................................ 9

Figure 2: Relative Variability in Prices, 1933 to 2005...........................................................................12

Figure 3: Nominal NYSE and AMEX Equal Weighed Average Price by Size Quintile.......................14

Figure 4: Nominal Value-Weighted and Equal-Weighted Average IPO and Newly Listed Prices of

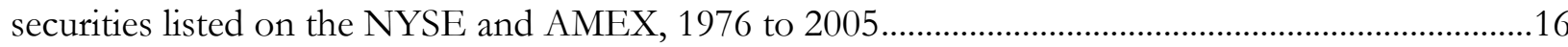

Figure 5: Nominal and Real Equal-Weighted Average Net Asset Value per Share of Open End

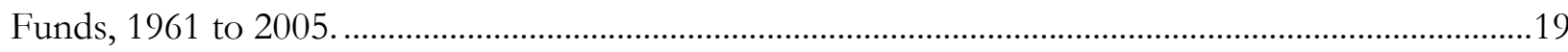

Figure 6: Nominal Trade-Weighted Average Price per Share and Benchmark Index, Tokyo Stock

Exchange

Figure 7: Nominal Trade-Weighted Average Price per Share and Benchmark Index, London Stock

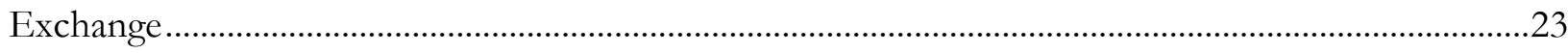

Figure 8: Nominal Trade-Weighted Average Price per Share and Benchmark Index, New York Stock

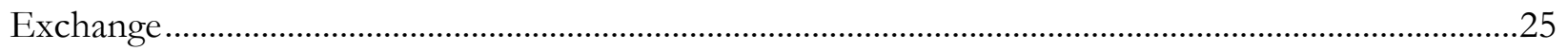

Figure 9: Nominal Equal Weighted Average Price per Share of Securities Listed on the NYSE

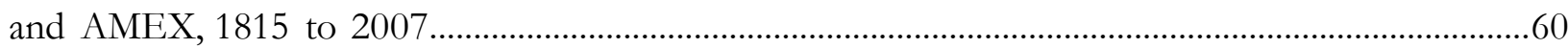




\section{LIST OF TABLES}

Table 1: Selected Prices and Splits on the NYSE, 1933 to 2005 ............................................................

Table 2: Summary of Prices, Returns, and Splits on the NYSE and AMEX......................................10

Table 3 Price and Split Distributions by Returns....................................................................................11

Table 4: Summary of Initial Listings by Size Quintiles and Date .........................................................17

Table 5: Relationship of Nominal Stock Price and Index Returns in International Markets..............27

Table 6: Prices and Trading Costs over 80 Years .................................................................................29

Table 7: The Price Targeted by Mangers via Stock Splits ......................................................................65 


\section{Introduction}

Evolution generally results in organisms that seem well adapted to their environment. However, many animals have vestigial structures that once served a purpose but no longer do, such as the human appendix. Societies and cultures show strong evidence of norms, a societal analog of an evolutionarily inherited trait. For example, people in the UK and many of its ex-colonies drive on the left hand side of the road, and the Mursi people of southern Ethiopia, among many others, insert plates into their lips because of a longstanding norm about beauty (Turton (2004)). These are two examples of norms, which despite arising from historical accident, still serve their cultures well. Many societal customs appear to be vestigial remnants from earlier generations as well. For example, the tradition of wearing neckties began in the sixteenth century when men donned linen cravats, which served the sensible purpose of a bib or napkin. Although silk neckties still collect stains, they no longer serve any practical function.

The question I investigate in this paper is whether vestigial norms and customs affect corporate decision making. Consider the following fact: The average nominal price for a share of stock on the New York Stock exchange has remained roughly constant (about \$30-\$40) since the Great Depression. The mechanism that has

allowed share prices to remain remarkably constant for over 70 years is stock splits. 
For example, in Table 1, I report the average prices of six well know securities for each decade starting in 1935 until 2005. 
Table 1: Selected Prices and Splits on the NYSE, 1933 to $2005^{1}$

Panel A: Average Price

\begin{tabular}{lllllll}
\hline Sample Years & ADM & ED & GE & GM & HSY & UVV \\
\hline $1933-1935$ & $\$ 32.58$ & $\$ 34.68$ & $\$ 22.80$ & $\$ 32.43$ & $\$ 63.50$ & $\$ 17.99$ \\
$1936-1945$ & $\$ 36.80$ & $\$ 26.44$ & $\$ 38.23$ & $\$ 51.16$ & $\$ 59.37$ & $\$ 11.05$ \\
$1946-1955$ & $\$ 39.54$ & $\$ 33.48$ & $\$ 51.86$ & $\$ 66.96$ & $\$ 46.69$ & $\$ 26.79$ \\
$1956-1965$ & $\$ 37.73$ & $\$ 65.41$ & $\$ 76.41$ & $\$ 58.90$ & $\$ 66.60$ & $\$ 37.07$ \\
$1966-1975$ & $\$ 39.42$ & $\$ 25.58$ & $\$ 75.32$ & $\$ 70.46$ & $\$ 22.95$ & $\$ 21.26$ \\
$1976-1985$ & $\$ 21.32$ & $\$ 25.13$ & $\$ 58.43$ & $\$ 60.96$ & $\$ 31.08$ & $\$ 20.79$ \\
$1986-1995$ & $\$ 23.39$ & $\$ 34.10$ & $\$ 67.57$ & $\$ 53.49$ & $\$ 40.94$ & $\$ 37.96$ \\
$1996-2005$ & $\$ 16.43$ & $\$ 39.32$ & $\$ 62.14$ & $\$ 53.64$ & $\$ 61.91$ & $\$ 27.28$ \\
Average & $\$ 30.74$ & $\$ 35.60$ & $\$ 59.84$ & $\$ 58.26$ & $\$ 47.75$ & $\$ 25.70$ \\
\hline
\end{tabular}

Panel B: Average UnSplit Price

\begin{tabular}{lllllll}
\hline Sample Years & ADM & ED & GE & GM & HSY & UVV \\
\hline $1933-1935$ & $\$ 32.58$ & $\$ 34.68$ & $\$ 22.80$ & $\$ 32.43$ & $\$ 63.50$ & $\$ 17.99$ \\
$1936-1945$ & $\$ 40.15$ & $\$ 26.44$ & $\$ 38.23$ & $\$ 51.16$ & $\$ 59.37$ & $\$ 11.05$ \\
$1946-1955$ & $\$ 118.62$ & $\$ 33.48$ & $\$ 69.68$ & $\$ 111.96$ & $\$ 114.78$ & $\$ 29.66$ \\
$1956-1965$ & $\$ 113.18$ & $\$ 69.89$ & $\$ 229.22$ & $\$ 353.41$ & $\$ 384.33$ & $\$ 83.85$ \\
$1966-1975$ & $\$ 299.82$ & $\$ 51.16$ & $\$ 302.33$ & $\$ 422.75$ & $\$ 358.13$ & $\$ 85.03$ \\
$1976-1985$ & $\$ 1,300.40$ & $\$ 69.43$ & $\$ 439.58$ & $\$ 365.79$ & $\$ 631.65$ & $\$ 83.15$ \\
$1986-1995$ & $\$ 5,879.48$ & $\$ 211.60$ & $\$ 1,738.45$ & $\$ 500.29$ & $\$ 3,580.41$ & $\$ 174.15$ \\
$1996-2005$ & $\$ 10,157.04$ & $\$ 314.54$ & $\$ 9,630.20$ & $\$ 643.63$ & $\$ 13,003.05$ & $\$ 218.25$ \\
Cumulative Split & $\mathbf{6 7 9 : 1}$ & $\mathbf{8 : 1}$ & $\mathbf{2 8 8}: \mathbf{1}$ & $\mathbf{1 2}: \mathbf{1}$ & $\mathbf{3 7 5}: \mathbf{1}$ & $\mathbf{8}: \mathbf{1}$ \\
\hline
\end{tabular}

\footnotetext{
${ }^{1}$ Data is from The Center for Research in Security Prices (CRSP). I select six well-known companies that have survived from 1933 to the present as representative examples. Over each time period, I calculate the average month end closing price (Panel A) and the average of what would have been the month end closing price if the firm had never issued any stock splits or stock dividends (Panel B). Cumulative Split is the magnitude of the accumulated stock splits and stock dividends undertaken by the company from January 1933 to December 2005. ADM is Archers Daniel Midland Co., ED is Consolidated Edison, Inc, GE is General Electric, GM is General Motors, HSY is The Hershey Company, and UVV is the ticker symbol for Allegheny Energy Inc.
} 
However, the existence of stock splits is merely a necessary, but not sufficient, condition for nominal process to remain stable. In fact, stock splits could have been used to create almost any time series of nominal prices. Research on stock splits has proposed some theoretical explanations of why managers may choose to split their stock, but these proposed models fail to predict that nominal share prices would remain constant. ${ }^{2}$

To illustrate the phenomenon, consider the case of General Electric (GE). On December 31,1935 , GE was trading at $\$ 38.25$ a share and exactly 72 years later, it was trading at $\$ 37.07$ a share. Had GE never split its shares from 1933 to 2007, its share price on December 31, 2007, would have been $\$ 10,676.16$. In fact, it has split its stock seven times over this time period, resulting in a cumulative split of 288:1, and each targeted price was about the same. GE, like most firms, is pro-active at keeping its nominal share price constant by splitting its shares. I argue that in so doing, GE and most other U.S. firms follow a norm that keeps their nominal share prices in a narrow and roughly constant range through time.

\footnotetext{
${ }^{2}$ I focus on the role of stock splits in setting prices, rather than cash dividends or other corporate actions, because a stock split is, at least on a first order approximation, strictly cosmetic- nothing fundamental about the firm changes. The firm does not reduce its cash balance or retained earnings as they would in a cash dividend, no money is transferred from the firm to investors. Investors merely trade one share of old stock in exchange for, say, two new shares, each of which represents an economic right in the firm that is exactly one half of the right of their old share.
} 
Furthermore, while it may have made sense to maintain share prices in this range for some time period, it is difficult to think of a rationale that could support a constant share price as being optimal over the past seventy two years.

Adhering to the norm and actively maintaining nominal stock prices in a narrow band through stock splits is costly. Based on discussions with lawyers and bankers who have been involved in these transactions I estimate the direct administrative costs of splits currently to be in the range of $\$ 250,000$ to $\$ 800,000$ for a large firm, which is similar to the estimate offered by Ryser (1996). Sosnick (1961) provides a cost estimate for the earlier part of my sample. He estimates dollar costs as a function of the payout ratio on a stock distribution, and reports costs of $\$ 250,000$ for a 2 percent distribution, $\$ 330,000$ for a 5 percent distribution, $\$ 2,600,000$ for a 200 percent distribution, and $\$ 6,300,000$ for a 500 percent distribution.

However, this direct cost is dwarfed by the costs imposed on shareholders. First, the relative bid-ask spread increases after splits (Copeland, 1979; Conroy, Harris, and Benet, 1990; Kadapakkam, Krishnamurthy, and Tse, 2005), which increases trading costs for all investors. (The relative bid-ask spread is defined as the posted bid price, less the posted ask price, scaled by the bid-ask midpoint, and is a measure of cost of trading a stock for investors.) Second, institutional investors (at least since the mid-1970s) tend to pay a fixed brokerage commission per share, regardless of share price. (I use the term institutional investor to describe professional money managers, 
as opposed to retail investors.) Thus, trading 288 shares of GE at $\$ 37.07$ would be significantly more expensive than trading a single share at $\$ 10,676.16$. Had GE never split its stock (and everything else had remained the same), investors could have saved more than 99 percent of their brokerage commissions-which would save those trading GE stock about $\$ 100$ million a year in commissions. ${ }^{3}$ Third, the New York Stock Exchange charges a per-share fee to companies listed on its exchange, so this fee increases after a split.

Given the negative economic consequences for investors, why do firms proactively keep their share prices in a nominally constant narrow band? I suggest norms as a potential explanation. The role of norms in economics has been established as a mechanism to coordinate actions in settings where there are multiple equilibria (Wärneryd (1994)). "Social norms are customary rules of behavior that coordinate our interactions with others... (a norm) continues in force because we prefer to conform to the rule given the expectation that others are going to conform.” (Young (2008)). My investigation points to a specific norm about nominal share prices, and how it has continued in force long after any possible benefit of coordination on this specific equilibrium has dissipated.

\footnotetext{
3 The number in the text is based on a cost estimate of 2 cents/share, which I believe to be conservative. In discussions with several large and active money managers, I have been told that commissions are typically between 3 and 5 cents per share. The total cost estimate is also conservative by a factor of two, as each trade involves a buyer and seller. In essence, I am assuming that each trade is a trade with the market maker, and none of the trades are driven by institutions on both the buy and sell side, each of which would have to pay the commission.
} 
In the next section I describe facts and patterns relevant to constant share prices, as any satisfactory explanation for the nominal share price puzzle should be consistent with all these facts. Next, I discuss whether economic hypotheses about optimal trading-ranges or about signaling can explain why share prices are nominally constant. I then explain some of the implications of norms on optimal price ranges and describe some possible reasons why the average price norm was set to $\$ 30 \mathrm{a}$ share.

\section{Facts and Patterns}

\section{U.S. share prices have remained constant since the Great Depression.}

Figure 1, Panel A displays the annual average share price of every stock from the New York Stock Exchange (NYSE) and the American Stock Exchange (AMEX) from 1933 through 2007. The equally weighted average of share prices remained close to $\$ 25$ throughout the entire period. While the value-weighted price is higher, with a mean of $\$ 36.56$, the overall pattern is similar, suggesting that the results are not driven by just a few large stocks. As a reference, the Consumer Price Index experienced a geometric average annual inflation of 3.5 percent over this time, for a cumulative increase of 1,528 percent. Therefore, maintaining constant nominal prices resulted in a dramatic decrease in real prices. Figure 1, Panel B illustrates that real share prices have declined by more than 90 percent over this period. The equivalent, in today's 
dollars, of average stock prices from the 1930s and 1940s is a price per share of around $\$ 450$ ! Not only do the mean and median nominal prices remain constant, but there is also no trend in the cross-sectional variability of share prices, which has remained roughly constant over the last 72 years, as shown in Figure 2. 


\section{Figure 1: Average Prices of Securities on the NYSE and AMEX, 1933 to $2007^{4}$}
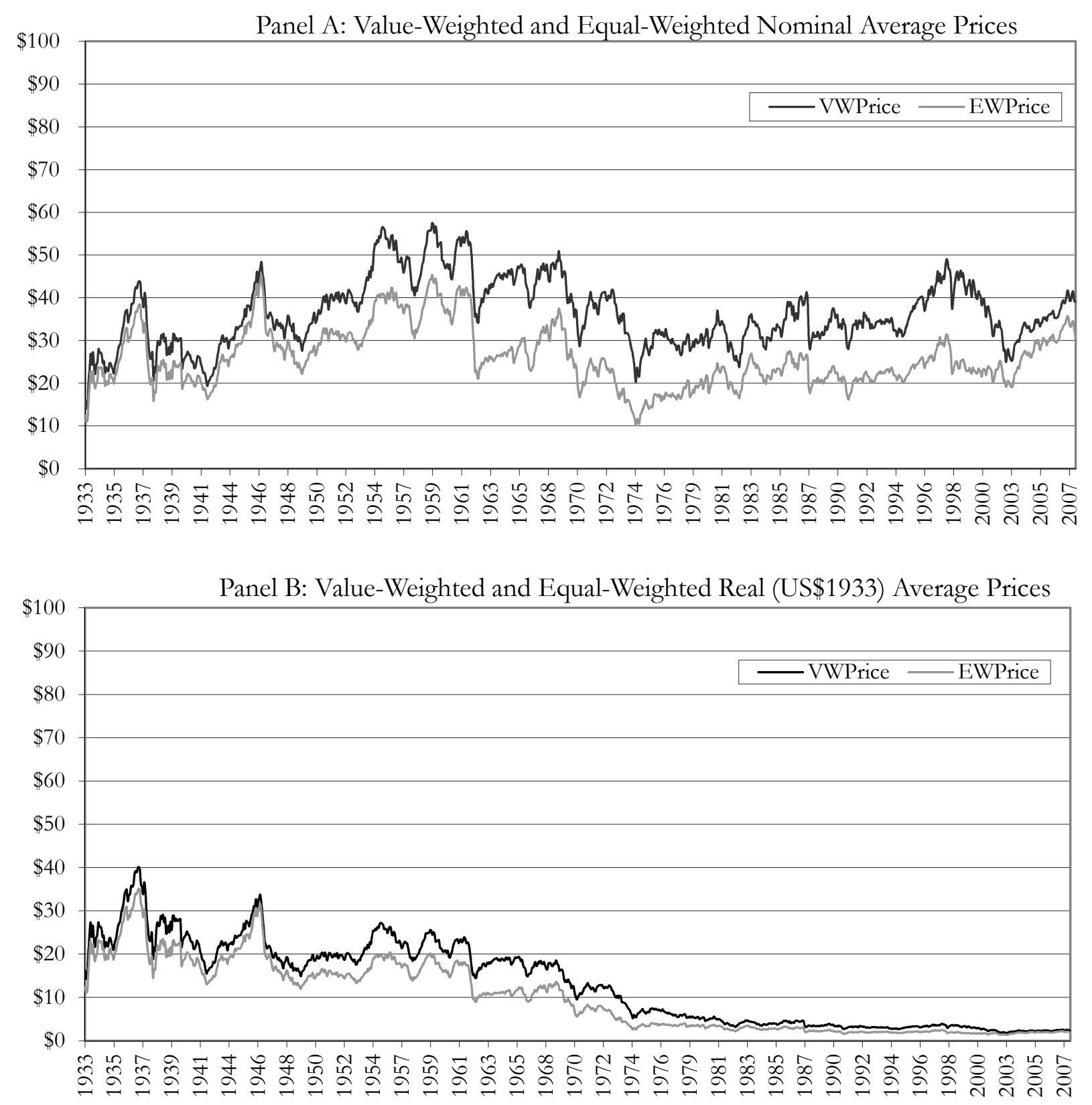

\footnotetext{
${ }^{4}$ Data is from the Center for Research in Security Prices (CRSP). These figures show the time series of value-weighted averages and equal-weighted averages of security prices. Data includes all ordinary common shares that are listed on the New York Stock Exchange and American Stock Exchange, but excludes Berkshire Hathaway. If Berkshire Hathaway is retained in the sample, the results are quantitatively similar for the value-weighted average price but significantly higher for the equalweighted average price post-1996. Nominal averages are calculated without adjustment. Real averages are presented in 1933 dollars, using monthly inflation data from the Bureau of Labor Statistics Consumer Price Index for "All Urban Consumers, U.S."
} 
Table 2: Summary of Prices, Returns, and Splits on the NYSE and AMEX. ${ }^{5}$

\begin{tabular}{rrrrrrr}
\hline $\begin{array}{r}\text { 10 Years } \\
\text { Ending }\end{array}$ & VW Price & $\begin{array}{r}\text { EW } \\
\text { Price }\end{array}$ & VWReturn & EWReturn & $\begin{array}{r}\text { \# of } \\
\text { Splits }\end{array}$ & Split Size \\
\hline 1935 & $\$ 41.59$ & $\$ 41.16$ & $14.89 \%$ & $8.30 \%$ & 390 & $1.59: 1$ \\
1945 & $\$ 30.63$ & $\$ 25.74$ & $14.01 \%$ & $17.65 \%$ & 150 & $1.93: 1$ \\
1955 & $\$ 40.30$ & $\$ 31.45$ & $18.15 \%$ & $13.04 \%$ & 823 & $1.65: 1$ \\
1965 & $\$ 47.56$ & $\$ 34.15$ & $14.85 \%$ & $12.86 \%$ & 2,121 & $1.42: 1$ \\
1975 & $\$ 37.07$ & $\$ 23.43$ & $9.45 \%$ & $4.99 \%$ & 2,932 & $1.43: 1$ \\
1985 & $\$ 31.00$ & $\$ 20.28$ & $22.40 \%$ & $24.65 \%$ & 3,038 & $1.53: 1$ \\
1995 & $\$ 34.15$ & $\$ 22.11$ & $20.29 \%$ & $12.39 \%$ & 2,209 & $1.56: 1$ \\
2005 & $\$ 36.03$ & $\$ 25.10$ & $20.25 \%$ & $14.74 \%$ & 1,938 & $1.64: 1$ \\
Average & $\$ \mathbf{3 7 . 2 9}$ & $\mathbf{\$ 2 7 . 9 3}$ & & & 170 & $\mathbf{1 . 5 3 : 1}$ \\
\hline
\end{tabular}

\footnotetext{
${ }^{5}$ Data is from The Center for Research in Security Prices (CRSP), and includes all ordinary common shares (SHRCD $=10,11,12)$ that are listed on the NYSE and AMEX exchanges (EXCHCD $=1,2$, 31, 32), but excludes Berkshire Hathaway (PERMNO=17778, 83443). For each 10 year period, I calculate the VW Price and the EW Price as the time series average of the monthly VW and EW prices respectively. The number of splits represents the sum of all stock splits and stock dividends (DISTCD $=5523,5532,5533,5543,5552,5553)$. If a firm makes multiple stock distributions in one month, I count this as a single stock distribution. The split size is the average of (1+FACSHR), and represents the number of shares one would hold at the end of the distribution. If Berkshire Hathaway is retained in the sample, the results are quantitatively similar for VW Price but significantly higher for EW Price post 1996. Returns are reported as the geometric annual average return over the sample period, Average Splits is an annual average number of splits, and Split Size is the implied average annual split ratio.
} 
Table 3 Price and Split Distributions by Returns. ${ }^{6}$

\begin{tabular}{rrrrrr}
\hline Return Decile & Pricet=0 & GCRETX & E[Pricet=T] & Split & Pricet=T \\
\hline 1 & $\$ 15.38$ & $-21 \%$ & $\$ 4.86$ & $1.21: 1$ & $\$ 4.00$ \\
2 & $\$ 17.75$ & $-9 \%$ & $\$ 10.80$ & $1.15: 1$ & $\$ 9.38$ \\
3 & $\$ 19.50$ & $-4 \%$ & $\$ 15.60$ & $1.16: 1$ & $\$ 13.50$ \\
4 & $\$ 18.88$ & $-1 \%$ & $\$ 17.98$ & $1.15: 1$ & $\$ 15.63$ \\
5 & $\$ 19.75$ & $2 \%$ & $\$ 21.72$ & $1.17: 1$ & $\$ 18.50$ \\
6 & $\$ 21.13$ & $5 \%$ & $\$ 27.25$ & $1.21: 1$ & $\$ 22.50$ \\
7 & $\$ 20.44$ & $9 \%$ & $\$ 31.29$ & $1.32: 1$ & $\$ 23.63$ \\
8 & $\$ 20.25$ & $13 \%$ & $\$ 37.69$ & $1.42: 1$ & $\$ 26.63$ \\
9 & $\$ 18.75$ & $19 \%$ & $\$ 45.08$ & $1.60: 1$ & $\$ 28.25$ \\
10 & $\$ 14.50$ & $31 \%$ & $\$ 55.61$ & $1.80: 1$ & $\$ 30.88$ \\
\hline
\end{tabular}

6 Data is from CRSP as described above. I divide the data into non-overlapping five year intervals from 1930 to 2004. For each of these 15 sub-samples, I rank the securities into deciles based on their cumulative return excluding dividends ("CRETX") over the sub-sample period. For each decile, I obtain the median price at the beginning of the sub-sample ("Price $\mathrm{t}_{\mathrm{t}=0}$ "), the median CRETX, and the median price at the end of the sample ("Price $\mathrm{t}_{\mathrm{t}=\mathrm{T}}$ "). "Split" is the implied split ratio for firms in each decile that generates the difference between the expected price at the end of the period ("E[Price $\left.\mathrm{t}_{\mathrm{t}=\mathrm{T}}\right]$ "), defined by Price $_{\mathrm{t}=0} * \mathrm{CRETX}$ and the actual price at the end of the period Price $_{\mathrm{t}=\mathrm{T}}$. I report the time series average of the results by decile below. The results using means, instead of medians, is quantitatively similar to the reported results. 
Figure 2: Relative Variability in Prices, 1933 to $2005 .^{7}$

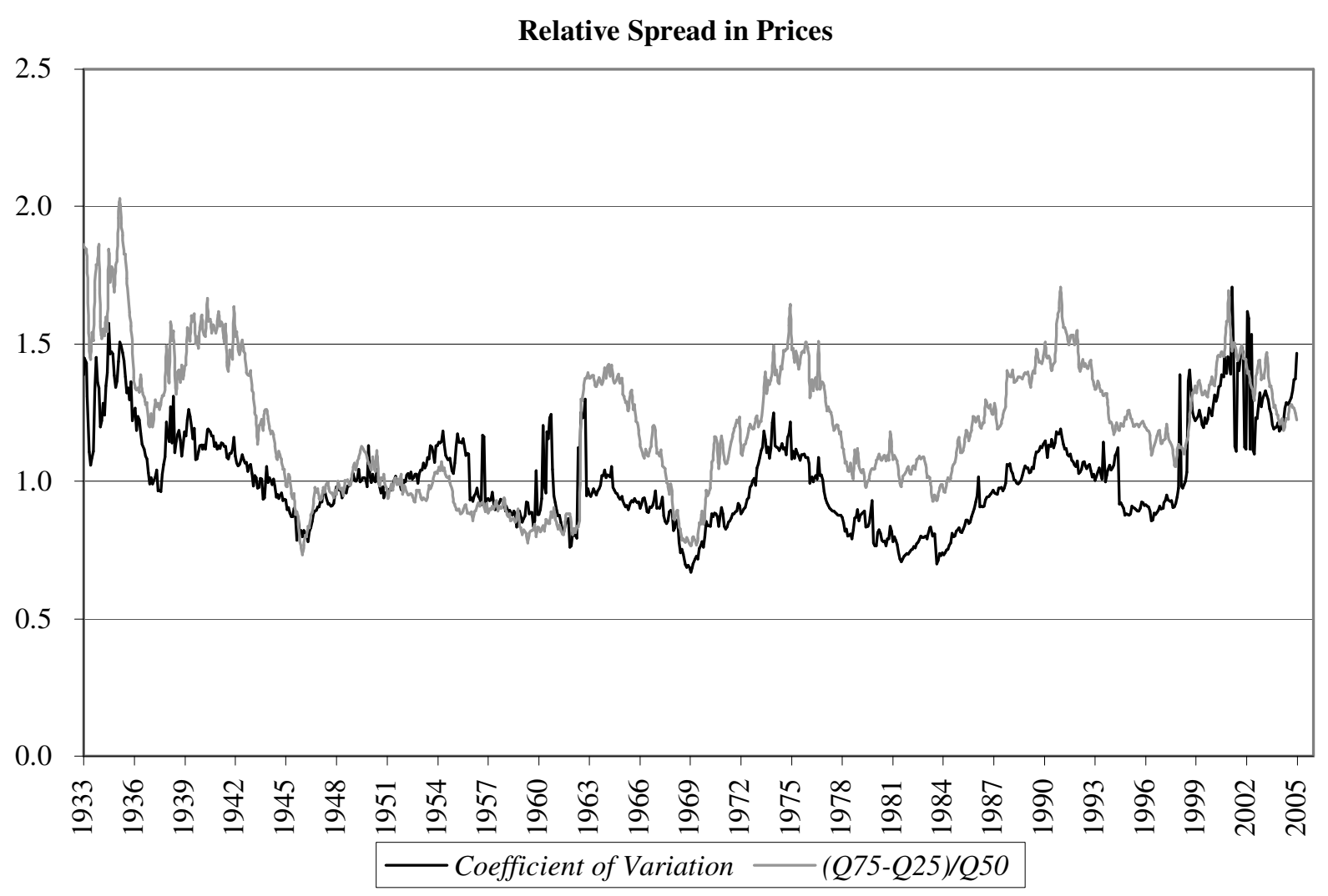

${ }^{7}$ This chart depicts the monthly coefficient of variation of stock prices and a non-parametric estimator that also measures the variability of stock prices. 


\section{Larger firms tend to have higher share prices.}

Figure 3 shows that large firms have had consistently higher share prices than small firms. For example, NYSE and AMEX firms in the top quintile of market capitalization tend to trade around $\$ 50$ a share. In contrast, firms in the bottom quintile tend to trade below $\$ 10$ a share. These findings imply that as firms "graduate" from one size group to the other--primarily through a combination of firm growth and accompanying share price appreciation--they adapt to the norms of their new peers and choose a new higher trading range for their shares. The correlation of firm size and share price is neither mechanical nor a result of listing requirements: all of the large firms could have selected different split ratios and achieved a low price per share. 
Figure 3: Nominal NYSE and AMEX Equal Weighed Average Price by Size Quintile $^{8}$

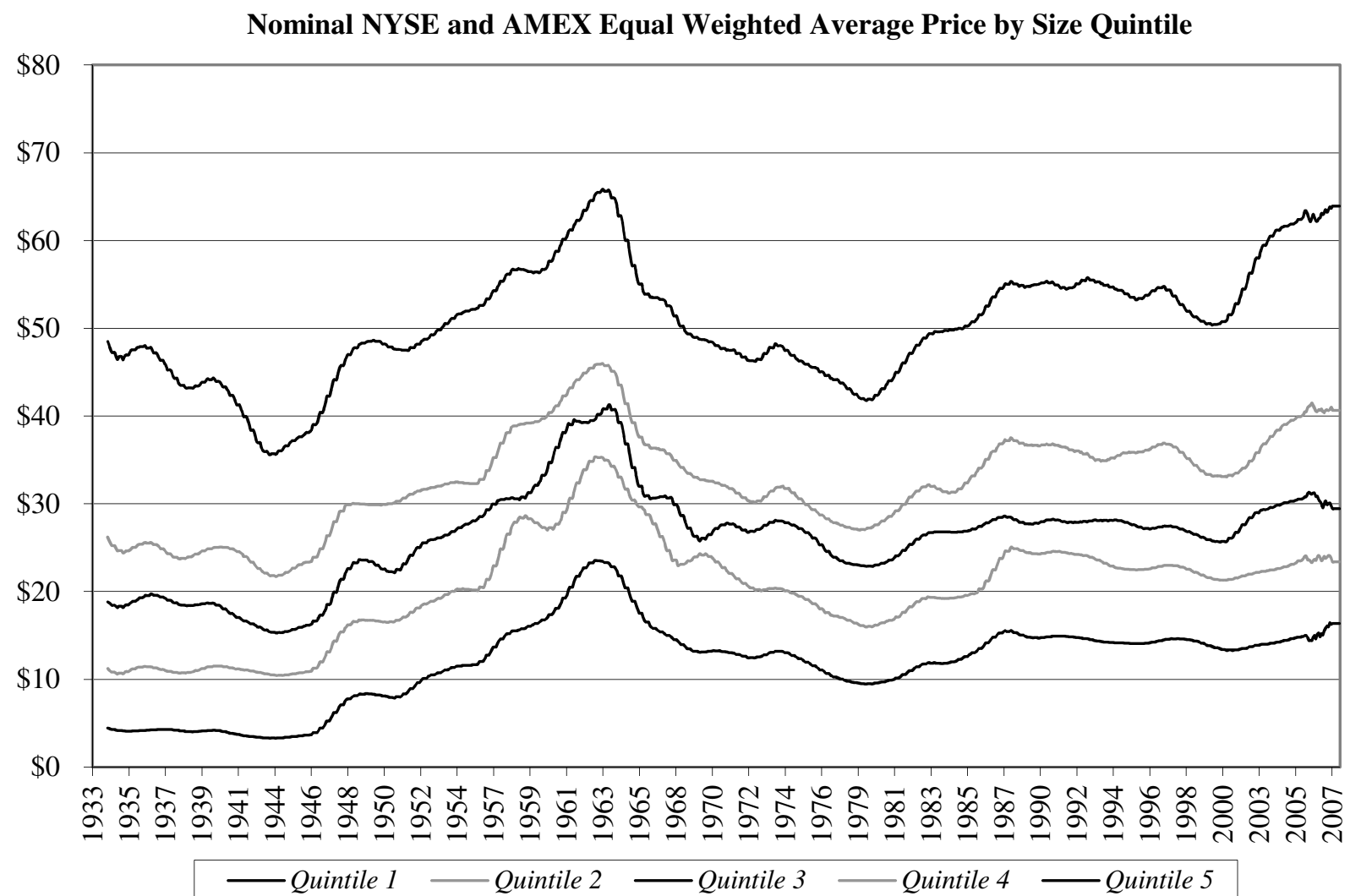

\footnotetext{
${ }^{8}$ The figure presents the twelve month average of equal weighted security prices by quintile. Quintile 1 are small firms, and have the lowest average prices, Quintile 5 are the largest firms, and have the highest average stock prices, and the relationship of average price and size is monotonic. The results are robust to size deciles.
} 


\section{Initial public offering share prices have remained constant.}

I find a pattern in the setting of new issue prices that is remarkably consistent with what I found for equity pricing in general. Initial public offerings have been issued at approximately the same share price since the Great Depression. Data on initial public offerings going back to 1976 (Figure 4, Panel A) shows that the offering price per share has remained in the $\$ 15-20$ range for the past 30 years. I also use the first appearance in the data collected by the Center for Research in Security Prices (CRSP) at the University of Chicago as a proxy for initial public offerings to extend the time series back to 1933 (Figure 4, Panel B). Again, the same picture emerges: if anything, prices of shares in initial public offerings were marginally higher in the 1950s, but have remained in a tight band since 1933. ${ }^{9}$ While share prices for initial public offerings are significantly lower than the average equal-weighted price of $\$ 25$, this is consistent with the size and price regularity described above. As shown in Table 4, Firms undertaking initial public offerings are smaller than the average listed firm, and their prices are consistent with the average share price of similar-size firms.

\footnotetext{
${ }^{9} \mathrm{I}$ also investigated the time series of IPO prices using the IPO data from Gompers and Lerner (2003). The results are quantitatively similar to those of the CRSP first appearance proxy. I thank Paul Gompers for his generosity in providing us with the data.
} 
Figure 4: Nominal Value-Weighted and Equal-Weighted Average IPO and Newly Listed Prices of securities listed on the NYSE and AMEX, 1976 to $2005^{10}$
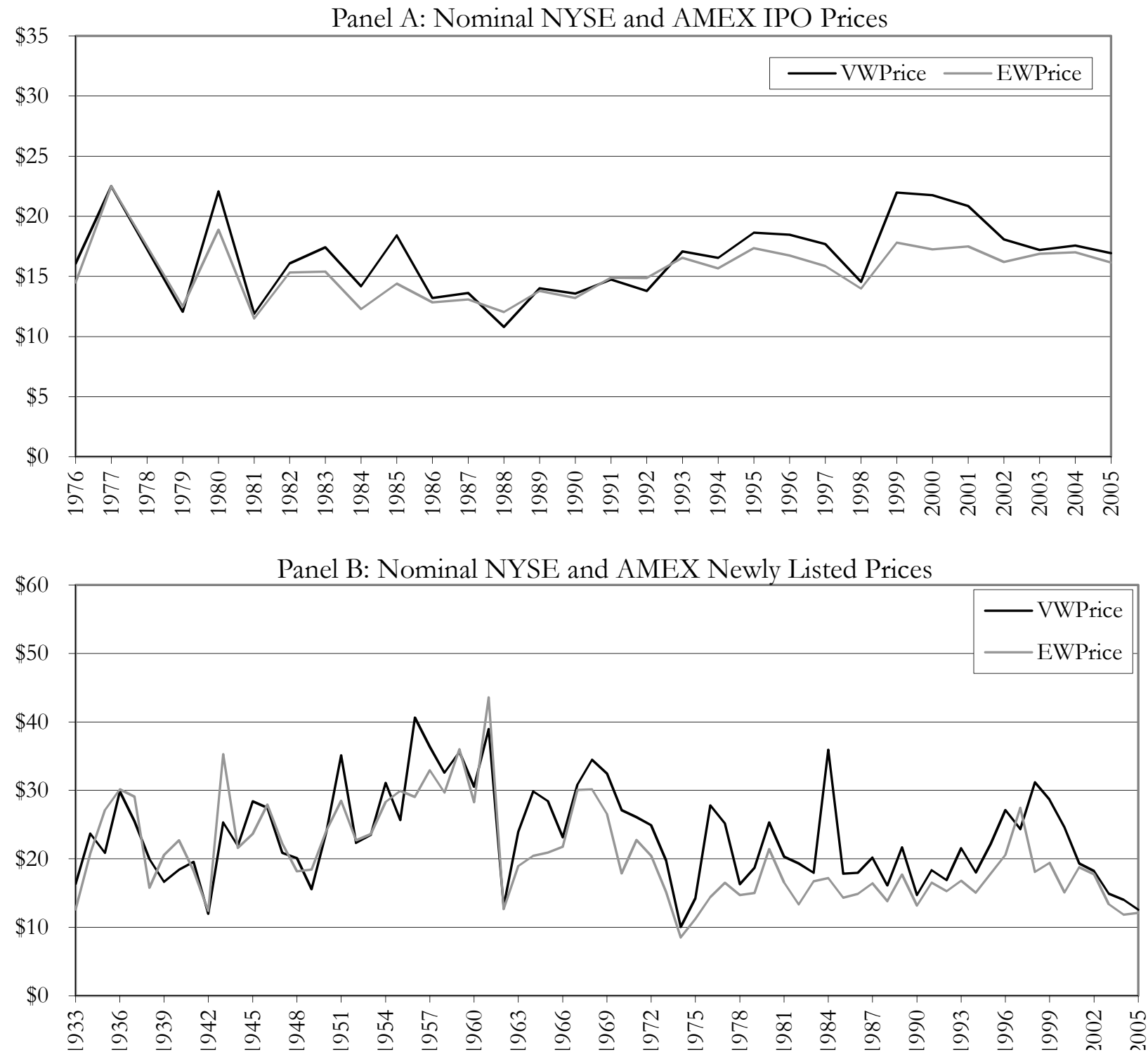

${ }^{10}$ Data is from SDC. I select those securities that are (i) IPOs (IPO Flag=Yes), (ii) Common Shares, (iii) Have an offer price greater than $\$ 4.99$, and whose primary exchange is the NYSE or the AMEX. There are few $(<20)$ observations prior to 1983 , so I caution against relying on the early part of the time series. To construct a longer time series that should approximate IPO pricing, I define "first appearance on CRSP" as a proxy for IPO, and take the month end price of the securities for this figure. I recognize that it is a noisy proxy for IPO pricing as it includes securities that "graduate" from other exchanges to the NYSE and AMEX. Excluding 1962 (the year that the AMEX enters the CRSP data) I have an average of 94 "first appearances" per year over the 1933 to 2005 period. 


\title{
Table 4: Summary of Initial Listings by Size Quintiles and Date ${ }^{11}$
}

\author{
Panel A: Distribution of New Listings by Size Quintile
}

\begin{tabular}{rrrrrr}
\hline Sample Years & Quintile 1 & Quintile 2 & Quintile 3 & Quintile 4 & Quintile 5 \\
\hline $1933-1935$ & $18.7 \%$ & $19.3 \%$ & $21.2 \%$ & $21.6 \%$ & $19.2 \%$ \\
$1936-1945$ & $6.4 \%$ & $30.1 \%$ & $38.6 \%$ & $18.6 \%$ & $6.4 \%$ \\
$1946-1955$ & $10.6 \%$ & $28.0 \%$ & $23.4 \%$ & $24.8 \%$ & $13.1 \%$ \\
$1956-1965$ & $32.3 \%$ & $31.8 \%$ & $21.5 \%$ & $9.8 \%$ & $4.6 \%$ \\
$1966-1975$ & $16.0 \%$ & $33.4 \%$ & $26.4 \%$ & $17.4 \%$ & $6.7 \%$ \\
$1976-1985$ & $21.3 \%$ & $34.5 \%$ & $22.7 \%$ & $14.0 \%$ & $7.4 \%$ \\
$1986-1995$ & $21.1 \%$ & $25.8 \%$ & $28.4 \%$ & $19.1 \%$ & $5.6 \%$ \\
$1996-2005$ & $27.1 \%$ & $25.8 \%$ & $23.6 \%$ & $16.2 \%$ & $7.2 \%$ \\
Average & $\mathbf{2 2 . 5 \%}$ & $\mathbf{2 8 . 5 \%}$ & $\mathbf{2 4 . 8 \%}$ & $\mathbf{1 6 . 5 \%}$ & $\mathbf{7 . 7 \%}$ \\
\hline
\end{tabular}

Panel B: Average Price of New Distributions by Size Quintile

\begin{tabular}{rrrrrr}
\hline Sample Years & Quintile 1 & Quintile 2 & Quintile 3 & Quintile 4 & Quintile 5 \\
\hline $1933-1935$ & $\$ 1.52$ & $\$ 5.22$ & $\$ 10.10$ & $\$ 18.13$ & $\$ 30.81$ \\
$1936-1945$ & $\$ 13.98$ & $\$ 18.66$ & $\$ 26.27$ & $\$ 30.95$ & $\$ 42.61$ \\
$1946-1955$ & $\$ 14.11$ & $\$ 21.49$ & $\$ 21.22$ & $\$ 28.99$ & $\$ 36.93$ \\
$1956-1965$ & $\$ 7.39$ & $\$ 15.23$ & $\$ 23.10$ & $\$ 33.10$ & $\$ 45.35$ \\
$1966-1975$ & $\$ 11.89$ & $\$ 17.27$ & $\$ 23.35$ & $\$ 32.20$ & $\$ 45.79$ \\
$1976-1985$ & $\$ 7.85$ & $\$ 12.89$ & $\$ 17.19$ & $\$ 23.89$ & $\$ 0.00$ \\
$1986-1995$ & $\$ 6.49$ & $\$ 11.25$ & $\$ 17.83$ & $\$ 24.92$ & $\$ 30.33$ \\
$1996-2005$ & $\$ 6.63$ & $\$ 13.53$ & $\$ 23.03$ & $\$ 32.49$ & $\$ 35.70$ \\
Average & $\$ 7.29$ & $\$ 13.97$ & $\$ \mathbf{2 0 . 4 6}$ & $\$ \mathbf{2 8 . 1 2}$ & $\$ \mathbf{3 6 . 6 9}$ \\
\hline
\end{tabular}

\footnotetext{
${ }^{11}$ Data is from CRSP as described above, except I exclude the year 1963 from this analysis as this is the first year the AMEX appears on the CRSP tape. I determine the size quintile to which each new listing on CRSP belongs, and report the results in 10 year sub-samples. Panel A shows the percentage of new listings by each quintile in each sub-sample. The overall average is an equal weighted average. Panel B shows newly listed prices by size quintile. Again, the overall averages are equal weighted averages. The average new listing price across the entire sample is $\$ 18.15$.
} 
4. Share prices of open-end mutual funds have remained roughly constant since the 1960s.

An investor who wants to invest in the shares of a mutual fund can send the money to the fund company and the fund will sell fractional shares in the mutual fund (calculated to three decimal places) as necessary. The price of a share in a mutual fund is a purely arbitrary number, a true numeraire. Nevertheless, mutual fund companies also have splits to keep share prices relatively constant, as seen in Figure 5.

Using the Mutual Fund Database from the Center for Research in Security Prices (CRSP), I find that from 1961 to 2007 the average open-end mutual fund net asset value per share drifted slightly upward. The average price is around $\$ 9$ per share in the first 20 years of the sample and around $\$ 13$ in the second part of the sample-about a 50 percent increase. However, this increase is very small when compared to cumulative increases in consumer prices of 605 percent and in stock returns of 11,250 percent over the same time period. 


\section{Figure 5: Nominal and Real Equal-Weighted Average Net Asset Value per Share of Open End Funds, 1961 to $2005 .{ }^{12}$}

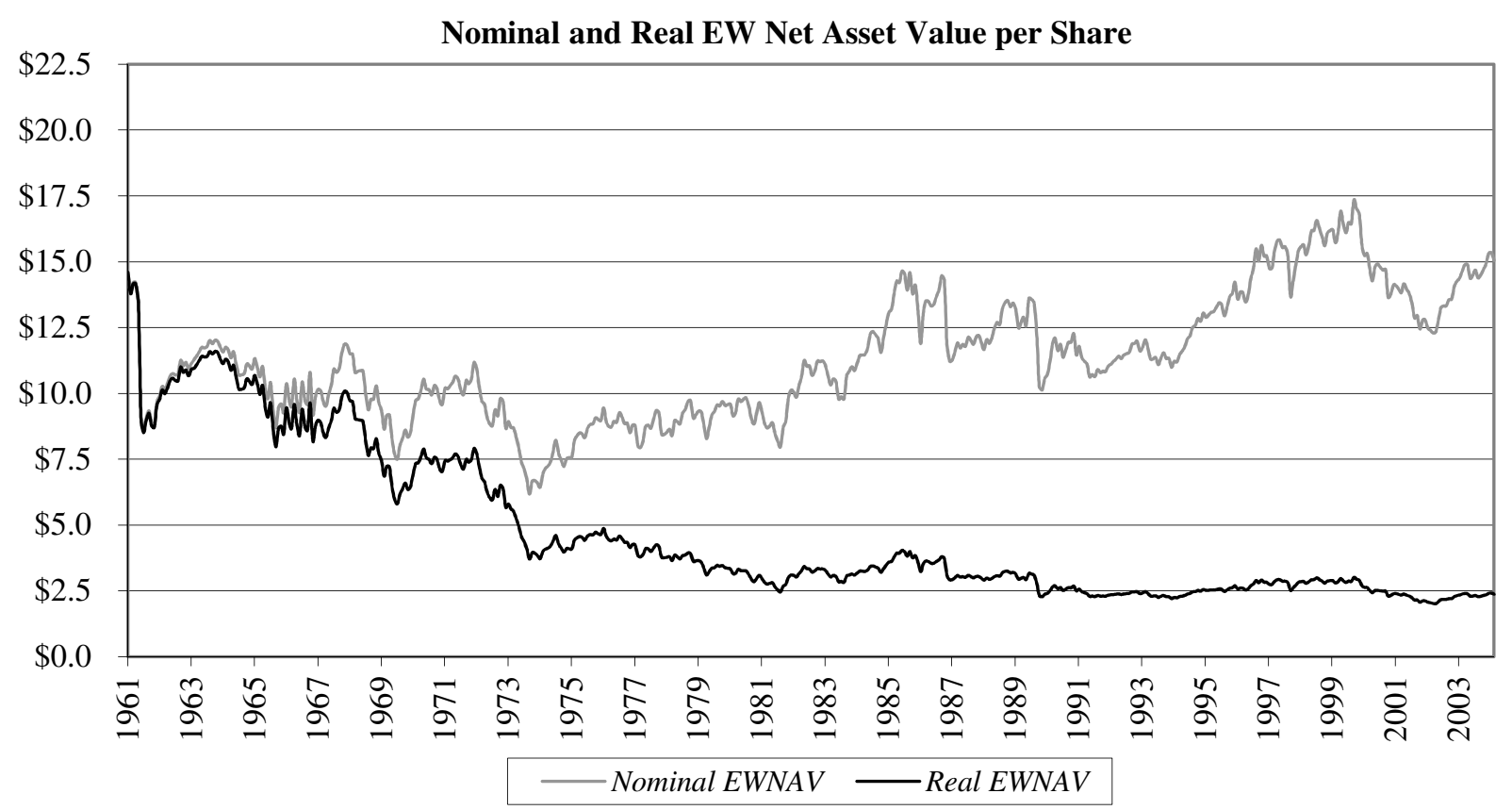

${ }^{12}$ Data is from the CRSP Mutual Fund Database. To proxy for equity funds, the data is screened to exclude those funds with a net asset value per share of less than $\$ 5$, and those funds that do not have a strong correlation with the market. Specifically, I regress each fund's return ("RETM") against the CRSP Value-Weighted Market Return ('VWRETD") and eliminate those funds that have an adjusted R-Square of less than 0.25. The BLS CPI is used to set all prices in 1961 dollars. 


\section{The pattern of share prices varies dramatically across countries.}

Consider the experience of the Tokyo Stock Exchange. The average nominal price for individual shares in Tokyo has fluctuated considerably; it rose from about $¥ 300$ / share in 1975 to $¥ 1500$ /share in 1990 , then dropped to about $¥ 800$ - $¥ 1000$ /share for most of the time from 1991 to 2005—although with a brief jump back to $¥ 1400$ /share in 2001. The main index for the Tokyo stock market, the Nikkei 225, has followed a similar pattern, generating a correlation of 0.85 (Figure 6). For example, from 1975 to 1990 the Nikkei 225 index increased by 436 percent and the average share price increased by a very similar 409 percent. Looking just at the 1980s, the Nikkei 225 increased ten-fold in market value, and average price of individual shares increased at the same pace--which suggests that large stock splits were rather rare in Japan. ${ }^{13}$ As the Nikkei 225 index declined after 1990, share prices declined as well.

${ }^{13}$ I thank Mr. Yamaguchi from Ibbotson Associates for sharing data and information on the Tokyo stock exchange. Greenwood (2008) provides comprehensive coverage of split activity in Japan, and documents that prior to 1999, over 95 percent of splits in Japan were in the form of what would be called small stock dividends in the United States. 


\section{Figure 6: Nominal Trade-Weighted Average Price per Share and Benchmark Index, Tokyo Stock Exchange ${ }^{14}$}

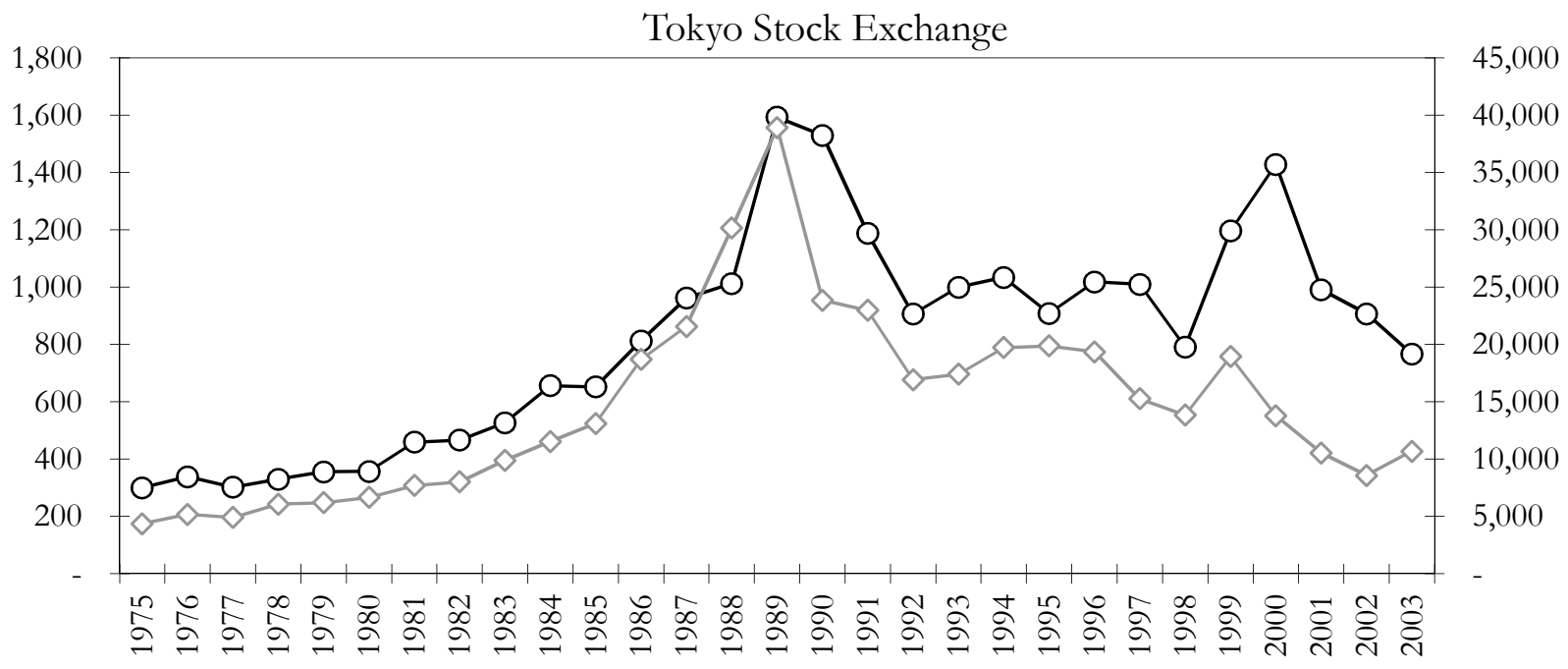

$-\mathrm{O}-$ Nominal Yen (LHScale)

$\checkmark$ Nikkei 225 Index, Nominal (RH Scale)

${ }^{14}$ Data for the international price figures and tables are from the World Stock Exchange Factbook, 2004 and World Federation of Exchanges Annual Reports. Trade-Weighted average price is calculated as the total value of shares traded on the exchange, divided by the total number of shares traded on the exchange. The Nikkei 225 Stock Index is reported from 1982 to 2003, and I use the Tokyo Stock Price Index for the pre-1982 time period. The Tokyo Stock Price Index is adjusted upwards by a factor of 13.5 to make its value in 1982 equivalent to that of the Nikkei 225 Index. For consistency of scale in comparisons of the Tokyo, London and New York stock exchanges, I force the left hand scale (which indicates the average price per share in local, nominal currency) to be comparable to the right hand scale (which indicates the annual index close level). 
Share prices in the United Kingdom are also not close to constant in nominal terms. Since 1981 (the first year of data), nominal share prices increased approximately from $£ 1.33$ per share to over $£ 4$ per share in 2000 , before falling back to $£ 2.99$ per share by 2005 . As in Japan, the average price of a share and the index of stock market returns, as measured by the FTSE Index, are highly correlated at 0.79 (Figure 7). For example, from 1981 to 1998 , average share prices rose from $£ 1.33$ to $£ 4.00$, a rise of 200 percent, while the FTSE index rose from 313 to 2,674, a rise of 750 percent. 
Figure 7: Nominal Trade-Weighted Average Price per Share and Benchmark Index, London Stock Exchange

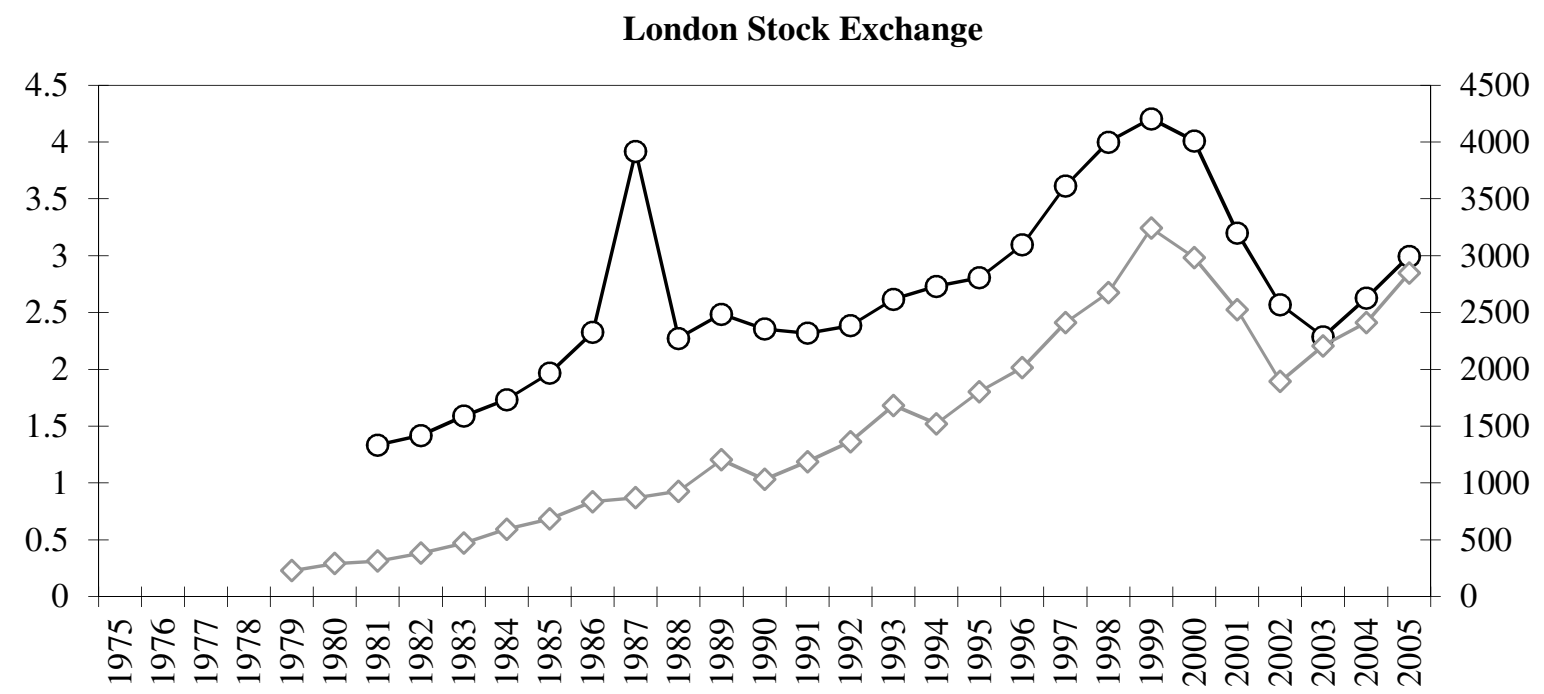

$\multimap-$ Nominal Pounds (LHScale) $\multimap-$ FTSE Actuaries All-Share Index, Nominal (RH Scale) 
Unlike Japan or the United Kingdom, U.S. share prices remained roughly constant over this time period while the index increases dramatically. For example, from 1975 to 2005, the Dow Jones Industrial index increased by 1,157 percent, but the average nominal share price changed only from $\$ 27.00$ to $\$ 34.98$, an increase of 30 percent (while consumer prices increased by 275 percent). In the United States, nominal share prices are only modestly correlated with the stock market index at 0.41 ; that is, in some cases share prices and the overall stock market index rise together, but then a number of corporations split their shares and the pattern is broken (Figure 8). The difference between the evolution of share prices in the United States as compared with the United Kingdom or Japan does not appear to be driven by different levels of inflation, as Tokyo nominal average share prices increased at approximately 2.4 times the rate of inflation, UK share prices at approximately 70 percent of the inflation rate, and U.S. average nominal share prices increased at only 10 percent of the rate of inflation..$^{15}$

${ }^{15}$ Japan inflation data is from the Japanese Ministry of Internal Affairs and Communication's Statistics Bureau, available at http://www.stat.go.jp/english/data/cpi/index.htm. UK inflation data is from the $\mathrm{CDKO}$ index, available at http://www.statistics.gov.uk/default.asp. 
Figure 8: Nominal Trade-Weighted Average Price per Share and Benchmark Index, New York Stock Exchange

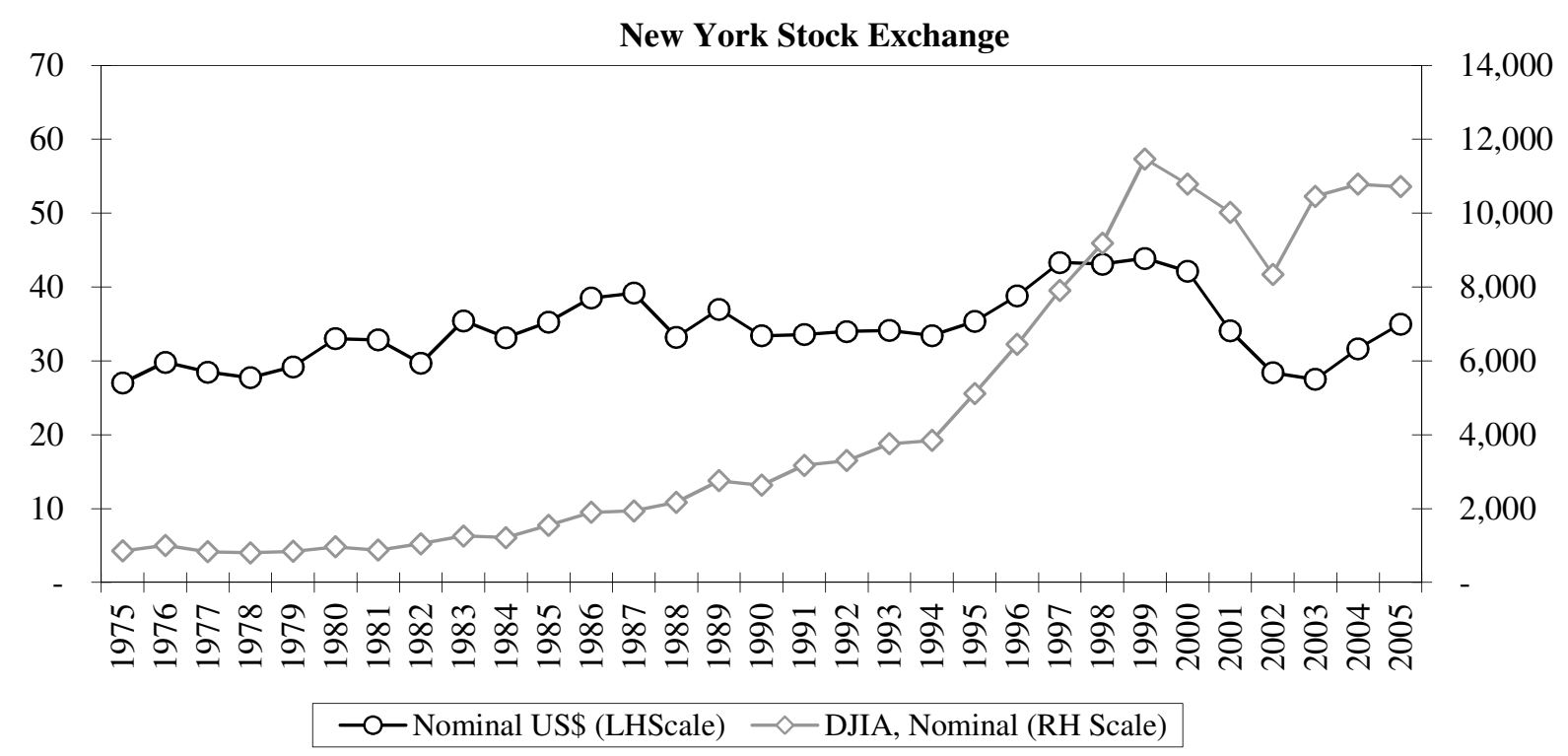


Firms in the United States, Japan and the United Kingdom all face a roughly similar business climate. Firms in all three countries have the ability through stock splits to maintain constant nominal prices-yet only U.S. firms do so. The United States is the only country where average share prices have remained essentially constant in nominal terms. The international evidence I present suggests that the underlying preference for a specific price point in the United States is probably not determined by some underlying fundamental economic reason.

In addition to London and Tokyo, I investigated share prices on 16 international stock exchanges, and found substantial cross sectional variation in terms of average stock price, variation of stock price, and covariation of average price for individual stocks and the overall value of the stock exchange index. The data, presented in Table 5, are suggestive of the fact that the nominal price fixation is primarily a U.S. or North American phenomenon. The NYSE to DJIA correlation is the lowest that I was able to estimate, at 0.41 , followed by the Toronto Stock Exchange, with $\varrho=0.64$. On the other extreme are the Johannesburg Stock Exchange, the Mexican and Italian Stock Exchanges with each having $\varrho>0.90$. The NYSE also has the smallest coefficient of variation over the time series of 0.14 , which is less than half of the variation on every other exchange (except for Toronto at 0.24 ). 
Table 5: Relationship of Nominal Stock Price and Index Returns in International Markets

\begin{tabular}{|c|c|c|c|c|c|c|c|}
\hline Exchange & Years & $\begin{array}{r}\text { Average } \\
\text { Price } \\
\text { (Current } \\
\text { US\$) }\end{array}$ & $\begin{array}{r}\text { Average } \\
\text { Nominal } \\
\text { Price }\end{array}$ & $\Delta$ Index & $\begin{array}{r}\Delta \\
\text { Nominal } \\
\text { Price }\end{array}$ & $\varrho$ & $\mathrm{CV}$ \\
\hline Australia & 1979-2005 & 2.23 & 2.01 & $9 \%$ & $5 \%$ & 0.81 & 0.33 \\
\hline Brussels & $1980-2004$ & 23.82 & $1,033.72$ & $11 \%$ & $3 \%$ & $(0.21)$ & 0.33 \\
\hline Italian & $1975-2004$ & 6.16 & $3,697.67$ & $12 \%$ & $8 \%$ & 0.93 & 0.73 \\
\hline Jakarta & $1977-2005$ & 0.08 & $4,169.84$ & $9 \%$ & $-9 \%$ & $(0.32)$ & 0.99 \\
\hline JSE (South Africa) & $1975-2005$ & 2.91 & 7.91 & $16 \%$ & $8 \%$ & 0.94 & 0.61 \\
\hline Korea & $1975-2005$ & 5.88 & $7,918.53$ & $27 \%$ & $6 \%$ & 0.70 & 0.97 \\
\hline Kuala Lumpur & $1975-2005$ & 0.50 & 2.95 & $8 \%$ & $-1 \%$ & 0.44 & 0.49 \\
\hline London & $1981-2005$ & 5.45 & 2.66 & $10 \%$ & $3 \%$ & 0.79 & 0.30 \\
\hline Mexican & $1975-2004$ & 1.66 & 5.60 & $46 \%$ & $20 \%$ & 0.90 & 1.14 \\
\hline NYSE & $1975-2005$ & 37.15 & 34.40 & $9 \%$ & $1 \%$ & 0.41 & 0.14 \\
\hline Philippine & $1980-2005$ & 0.02 & 0.43 & $9 \%$ & $14 \%$ & 0.36 & 1.08 \\
\hline Singapore & $1980-2005$ & 0.71 & 2.19 & $4 \%$ & $-5 \%$ & $(0.44)$ & 0.43 \\
\hline Taiwan & $1975-2005$ & 0.80 & 36.64 & $10 \%$ & $1 \%$ & 0.69 & 0.67 \\
\hline Thailand & $1975-2005$ & 0.22 & 108.25 & $7 \%$ & $-11 \%$ & $(0.37)$ & 0.82 \\
\hline Tokyo & $1975-2005$ & 8.33 & 820.70 & $6 \%$ & $4 \%$ & 0.85 & 0.43 \\
\hline Toronto & $1975-2005$ & 12.65 & 13.20 & $8 \%$ & $2 \%$ & 0.64 & 0.24 \\
\hline
\end{tabular}




\section{Maintaining constant prices increases trading costs}

Maintaining constant share prices through stock splits is costly for investors. First, as mentioned earlier, institutional investors and many individual investors pay a fixed commission per share or per trade. Even if commissions are as low as 2 cents a share, the cumulative costs are non-trivial. Second, I find that general trading costs are related to price level. I use Hasbrouck's (2006) data on prices and bid-ask spreads for several hundred stocks starting in the 1920s until 2005. This data is generated by sampling daily stock data to estimate bid-ask spreads for over 190,000 firm-year observations, and allows us to test the relation between prices and the cost of trading, defined as the relative bid-ask spread.

I regress the relative bid-ask spread on price, trading volume, turnover, and market capitalization on an annual basis, and report in Table 6 the time series averages of the annual coefficients (using what is called the Fama-Macbeth procedure (Fama and MacBeth, 1973). I find that higher priced firms have significantly lower relative bid-ask-spreads. For example, holding all else constant, a $\$ 5$ increase in stock price from $\$ 30$ to $\$ 35$ per share, decreases the relative bid-ask spread by approximately 9 percent. I also performed a robustness test using a non-parametric specification for price, and find quantitatively similar results. Consistent with tests which show that the relative bid-ask spread increases after splits, I find more generally that the specific price targeted by firms matters, and lower prices impose higher trading costs. 


\section{Table 6: Prices and Trading Costs over 80 Years $^{16}$}

$\begin{array}{lrrrr}\text { Variable } & \begin{array}{r}\text { Parameter } \\ \text { estimate }\end{array} & \begin{array}{r}\text { Standard } \\ \text { deviation }\end{array} & \text { t-value } & P \\ \text { Intercept } & 0.0109293 & 0.0047560 & 20.55 & <0.0001 \\ \text { Price } & -0.000102840 & 0.000070595 & -13.03 & <0.0001 \\ \text { Volume } & -9.997666 \mathrm{E}-8 & 1.5440817 \mathrm{E}-7 & -5.79 & <0.0001 \\ \text { Turnover } & -1.852681 \mathrm{E}-6 & 0.000117234 & -0.15 & 0.8820 \\ \text { Size } & 1.927482 \mathrm{E}-10 & 1.8602275 \mathrm{E}-9 & 0.93 & 0.3569\end{array}$

\footnotetext{
${ }^{16}$ Data is from Joel Hasbrouck's website and CRSP. There are 197,755 firm year observations and 80 years of data. I estimate the cost per dollar of trade for each security ("Cost"). Volume is the annual sum of the monthly volume ("Volume"). I estimate turnover as the total annual volume/monthly average of shares outstanding ("Turnover"). I estimate size as the monthly average price times monthly average number of shares outstanding ("Size"). I create dummy variables D1, D2, D3, D4 and D5 based on annual quintile ranking of the monthly average price of security. I use the Fama-MacBeth (1973) procedure for the two models shown below. I exclude Berkshire Hathaway and all stocks traded below $\$ 5 /$ share from the analysis, but the results are robust to their inclusion. My linear specification, with results shown in the table, is: Cost $=a+\beta 1[$ Price $]+\beta 2[$ Volume $]+\beta 3[$ Turnover $]+\beta 4[$ Size $]+$ e.

My nonparametric specification mentioned in the text was:

Cost $=\mathrm{a}_{1}\left[D_{1}\right]+\mathrm{a}_{2}\left[D_{2}\right]+\mathrm{a}_{3}\left[D_{3}\right]+\mathrm{a} 4\left[D_{4}\right]+\mathrm{a} 5\left[D_{5}\right]+\beta_{1}[$ Price $]+\beta_{2}[$ Volume $]+\beta 3$ $[$ Turnover $]+\beta 4[$ Size $]+e$
} 


\section{Economic Explanations}

Can this collection of facts about constant nominal stock price over time be explained by some standard economic explanation? Since the regularity is a result of firms splitting their stocks, I look to the stock split literature for possible explanations. A long literature about stock splits stresses three possible explanations for the act of splitting a stock: marketability, "pay to play" and signaling. I discuss them in turn.

\section{The Marketability Hypothesis}

One explanation for stock splits is that they are undertaken to increase the appeal of the stock to individual investors. A lower share price could increase the pool of potential investors in the company, and so the demand for the stock will increase. It is sometimes also argued that this will also increase the stock's liquidity. This argument has a long tradition and some empirical support, but it does not explain many of the key facts presented in the previous section.

Whittaker (1929) presents a comprehensive analysis of the meaning of a stock dividend and stock split. Starting as early as 1890 (e.g. Gibbons v. Mahon (136 U.S. 594)), there were a number of lawsuits surrounding the appropriate treatment of stock dividends in the case of what would currently be considered skipping generation income trusts. When a stock dividend was declared and paid, it was unclear as to whether this was income to be distributed to the current beneficiary of the income 
portion of the trust (generally a widow), or whether it was not income, in which case it was to be maintained as part of the principal portion on the trust which was held to the benefit of the subsequent trust beneficiary, known at the time as the "remainderman" (generally the children of the widow and the founder of the trust). This confusion as to how to treat a stock distribution extended into the realm of taxation as well. On a Federal level, the $16^{\text {th }}$ amendment gave Congress the power to tax incomes in 1913, and the Revenue Act of 1916 explicitly declared stock dividends to be taxable income. However, the Supreme Court in 1920 ruled this taxation of stock distributions to be unconstitutional (Eisner v. Macomber, 252 U.S. 189).

While this may seem to be merely an interesting historical note, it highlights the confusion around stock dividends and stock distributions which motivated the first economic papers which analyzed stock splits and stock dividends. Not only was there widespread confusion, but there was also a dramatic increase in the frequency and amount of stock distributions. A sample of 5,000 corporations that had sufficient data to permit analysis and were listed continuously from 1913 through 1926 provides evidence of the importance of stock distributions. $\$ 543$ million of stock dividends were paid from 1913 to 1920 (the "taxable period"), and $\$ 4,777$ million of stock dividends were paid from 1920 to 1929, for well in excess of a $775 \%$ increase. For comparative purposes, the same firms paid $\$ 5,693$ million in cash dividends, so the cash-dividend to stock-dividend ratio was approximately 1.2:1.0. 
Whittaker was one of the first papers to highlight the marketability issue as a possible motivation for stock distributions. "If shares that have a high market value (for example, $\$ 500$ ) are brought by a sufficiently large stock dividend to an ordinary level (perhaps $\$ 100$ ), the price is said to be brought within the trading range. This will in general be favorable to a more active market and wider distribution of the stock. Perhaps these effects are desired by the management." (pg. 33) While this is not the only rational Whittaker posits for stock distributions, it does suggest that there was a common belief in an "ordinary level" for stocks at approximately $\$ 100 /$ share prior to the Great Depression. Furthermore, it motivates much of the later work done in the area, including attempts to uncover managers' motivations for undertaking stock distributions.

Dolley's (1933) subsequent study specifically sought to address this question of managers' motivations through a survey of 88 corporations that had split their shares in the 1920s. Out of the 36 responding firms, 33 corporations reported that the primary objective was to increase the marketability of their common stocks. Furthermore, in his sample of 103 stock splits, 90 of the firms that split their shares had a stock price exceeding $\$ 100$ prior to the split, with some as high as $\$ 900 /$ share. In contrast, 95 of the firms split to a stock price under $\$ 100$. This price regularity is the first evidence he presents of the managers acting in a way that is consistent with their survey response. 
In addition to noting that splits are primarily undertaken by firms with high prices, and that the split ratio appears to be targeting a significantly lower price, the paper also presents evidence around whether this change in price did, in fact, increase the marketability of the shares. The paper shows limited evidence of any increase in trading volume (except for a temporary increase immediately around the share issuance/distribution), and a decrease in dollar volume traded after the split. So, it is unclear as to whether liquidity increases after the split.

However, consistent with the corporation's survey responses, there is a marked increase in the distribution of shares. Specifically, in a small sample of 38 respondents to a question in the survey about the number of shareholders, 36 firms reported a significant increase in the number of individual common shareholders one year subsequent to the share split.

Furthermore, despite considerable data limitations, the paper reports some positive price effect of the stock split. Approximately twice as many stock splits resulted in a price increase as compared to a price decrease. However, the change in price is quite small: for approximately two thirds of the sample that demonstrated some price impact of the stock split, the magnitude of the price impact was less than two points in absolute value.

While Dolley's (1933) survey results and empirical evidence are consistent with corporations targeting lower-priced shares to encourage broader ownership, there are 
two important considerations to note. First, the data used in the paper was less reliable than what modern researchers are accustomed to, and the analysis, while groundbreaking, was a bit more primitive than what is currently practiced. ${ }^{17}$ As an example of the data limitations, Dolley notes that a number of the firms in the survey also issued new shares (separate from the share split), and that the trading volume accompanying the price data used to measure price changes was often low, in some cases as little as 10 shares or 100 shares in a week. Because of this, the paper is careful to not make any claim about causality. Second, a $\$ 100$ nominal share price in 1925 was certainly more difficult for a retail investor to trade than a $\$ 100$ nominal share price in 2005 , due to inflation and numerous other factors.

Barker (1956) investigates 90 NYSE listed companies that executed a split with a ratio of 2:1 to 3:1 between 1951 and 1953. The most cited finding of this research seems to be that persistent abnormal returns were associated exclusively with firms that contemporaneously split their stock and also increased their cash dividend, and firms that only undertook a stock split, without an accompanying cash dividend increase, quickly reversed any announcement effect gains within six months and generated zero abnormal returns. More importantly for this discussion, however, was his finding that "The lower per-share price resulting from a stock split-up does bring the stock within the financial reach of more investors and traders." (pp 103-104) After

\footnotetext{
${ }^{17}$ For evidence on the novelty and importance of Dolley's work, Craig MacKinlay points to this work as one of (if not the) first published event study (MacKinlay (1997), p 13).
} 
matching the split firms to non-splitting firms in the same S\&P industry 34 subgroups, he finds an approximately 25 percent differential gain in the number of shareholders in splitting companies. While this may be a result of the stock split, he cannot rule out other channels that may have driven the increase in the number of shareholders (e.g. firms with higher performance could garner greater media and analyst coverage, leading to greater share ownership, independent of the stock split itself). So, I once again see limited direct empirical evidence of increased marketability due to share splits.

Eismann and Moses (1978) surveyed 80 firms (39 responses) which paid stock dividends and 89 firms (58 response) which did not pay a stock dividend in 1974. The motivation for this survey is the question that is repeatedly asked in the stock distribution literature: if we generally believe that stock distributions are primarily a cosmetic action, why do so many firms undertake this action? Of the six survey responses that had greater than 50 percent "agree" response rates, only one is consistent with a marketability explanation. 78.9 percent of stock dividend payers (and 60.3 percent of non-payers) agreed with the statement, "One effect of stock dividends is to ultimately increase the number of shareholders in the firm." Surprisingly, trading range as the mechanism for "marketability" appears to have no meaningful support. Only 34.2 percent of stock dividend payers agreed (while 34.2 percent expressed "no opinion" and 31.6 percent disagreed) and 20.7 percent of non-payers agreed (while 
19.0 percent expressed "no opinion" and 60.3 percent disagreed) with the statement "Stock dividends keep a firm's stock price in an optimal price range." Similarly, there is limited consensus in the survey as to whether the larger number of shares outstanding made the stock more attractive, or allowed small stockholders to purchase round lots. So, at least for stock distributions in the form of stock dividends, there was very limited survey evidence consistent with a marketability hypothesis.

Baker and Gallagher (1980) performed a survey modeled on the work of Eismann and Moses (1978), but focused on firms which undertook stock splits instead of stock dividends. The survey was of chief financial officers of two groups of firms, one that had split (100 firms, 63 responses) and another that had not (100 firms, 64 responses). For both groups, they report that the most popular reason for splitting is to "make it easier for small stockholders to purchase round lots (more shares, lower price)." Within the stock split group, 98.4 percent agreed with the marketability hypothesis, and even within the non-split group, 93.8 percent supported this claim of increased marketability of shares at lower prices. There was also significant support for two other statements. 93.7 percent of split firms (78.1 percent of non-split firms) agreed with the statement, “Stock splits keep a firm's stock price in an optimal price range" and 85.4 percent of split firms $(76.6$ percent of non-split firms) agreed with the statement, "One effect of stock splits is to ultimately increase the number of shareholders in the firm." Finally, 65.0 percent of managers who had 
affected a stock split listed the most important reason for so doing as leading to a lower share price (with over 50 percent explicitly invoking the lower price as a mechanism to obtain optimal trading range or attracting investors). 75.0 percent of non-split managers stated that they did not do a stock split because their price was already in or below the optimal range. So, in contrast to the stock dividend survey, the stock split survey provides evidence that managers are actively seeking to improve their shares' marketability through the direct targeting of a lower price. Furthermore, there appears to be little change in managers' belief that lower stock prices can be used to attract investors from 1930 to 1980.

Stock Splits (Baker and Powell (1993)) and stock dividends (Baker and Phillips (1993)) were again the subject of surveys in 1993. The stock split survey covered a larger sample of both NYSE and AMEX firms (248 surveys, 136 responses), and the stock dividend survey added coverage of NASDAQ firms (299 surveys, 136 responses). They also widened the scope of the earlier stock split surveys in an attempt to both update the previous studies, as well as provide evidence that could allow some test of the prevailing theories. Consistent with the Dolley (1933) and Baker and Gallagher (1980) results, the three statements with which stock splitting managers are most likely to agree in Baker and Powell's (1993) survey revolve around a preferred trading range being more attractive to investors, and allow for a broader ownership. Specifically, 93.3 percent of managers agree with the statement, "A stock 
split makes shares more attractive by lowering the stock price," 91.2 percent of respondents agree with the statement, “A stock split puts a firm's stock price in a preferred trading range," and 87.8 percent agreed with the statement, "Stock splits make it easier for small shareholders to buy shares in round lots." In Baker and Phillips (1993) survey of stock dividends, over 90 percent of managers agree with a primarily behavioral explanation, "Stock Dividends have a positive psychological impact on investors receiving them." In contrast to the earlier studies of stock dividends, the survey results exhibit an increased belief that stock dividends keep share prices in a preferred trading range, and a significantly decreased belief that stock dividends are a substitute for cash dividends. However, consistent with earlier surveys and with my norms hypothesis, the highest ranked motive continues to be the historical precedent. 42.9 percent of respondents list this as their primary motive for paying stock dividends.

The second potion of their survey provides further confirmatory evidence. 50.7 percent of managers listed moving the stock price into a better trading range as their primary rational for undertaking a split. Improving liquidity and signaling positive managerial beliefs about the firm's future prospects both received significant support as well. In an empirical analysis of the firms' split ratios and targeted prices, the authors find that the preferred trading range appears to be between $\$ 20$ and $\$ 35$. 
Interestingly, even some managers of open-end mutual funds support the trading-range hypothesis, with 40.4 percent agreeing that "a lower NAV [net asset value] per share attracts more investors" (Fernando et al, 1999).

Not only do managers appear to have this belief, but also several empirical studies have provided evidence that can be interpreted as supportive of the marketability hypothesis under certain conditions. Sosnick (1961) presents an early analysis of when the benefits of a stock distribution would outweigh its costs, and concludes "The potential benefits are greater convenience and value, and possibly conversion of odd lots, a lower odd lot differential... (and) wider ownership.... However, it seems unlikely that these various benefits would in fact outweigh the burdens unless price per share is very high - say above $\$ 200$ - and is brought into a popular price range... A ratio large enough to bring price per share below $\$ 40$ would decrease the odd lot differential, and a ratio large enough to bring the price below $\$ 20$ would reduce the rate of the New York stock transfer tax.”( page 69). So, while there is an explicitly described set of mechanisms that would allow for greater marketability, Sosnick argues that it would be most likely to be realized for very high priced stocks undergoing very large splits (of 5:1 or 10:1).

Nichols and McDonald (1983) find that split factors are positively correlated with pre-split share prices, and negatively correlated with market capitalization. Dyl and Elliott (2005) document a positive correlation between share price and 
institutional ownership, suggesting that individuals might prefer lower-priced stocks. Fernando et al. (2004) document a positive correlation between institutional ownership and share prices of initial public offerings. One could conclude that institutional investors prefer high share prices due to lower brokerage commissions, whereas individual investors can only afford buying round lots of low-priced shares.

However, direct tests of the increased marketability for common stocks subsequent to a stock split suggest that there is no long-term increase in marketability. For example, Copeland (1979) studies a random sample of 25 splits of 1.25:1 or greater by NYSE listed firms from 1963 to 1974, and finds volume is decreased following a split, and transaction costs increase by 27.51 percent (mean) or 7.92 percent (median). 162 OTC stocks (1968-1976) provide a separate sample for bid-ask spreads, which increase 4.95 percent to 6.79 percent of price for a 40 day window around the split. Copeland concludes that there is a permanent decrease in liquidity post-split. Lakonishok and Lev (1987) find that volume before and after a stock split are insignificantly different, as do Maloney and Mulherin (1992). Despite the lack of any increased trading volume, Lakonishok and Lev (1987) do note the possibility of increases of other measures of marketability (such as share ownership base), and Maloney and Mulherin (1992) find some evidence of an increase in the number of shareholders after the split, as well as an increased number of small trades. The increase in share ownership and retail investor ownership is supported in other studies 
as well. Lamoreaux and Poon (1987) investigate the time series from 1962 to 1985 for NYSE and AMEX listed stocks with splits of 1.5:1 or greater, and all reverse splits, resulting in 217 stock split observations, uncontaminated by other announcements in a three day window around the event. They find an increase in the number of shareholders in the year of a split by 34.65 percent, compared with a 2.11 percent decrease for control firms. They also find that the value of shares traded falls subsequent to ex-split day. These two facts combined are suggestive of one-time clientele shift. Easley, O'Hara, and Saar (2001), in a study of 72 NYSE stocks that undertook 2:1 splits in 1995, find results consistent with "preferred trading range", because of increased uninformed trading, and new clientele, but inconsistent with optimal tic size. They find no increase in liquidity, because of increase in informed trading and increased spreads based on increased volatility. Kadapakka, Krishnamurthy, and Tse (2005) find that the ex-date is associated with small investor buying and positive abnormal returns, but results do not hold post decimalization. Byun and Rozeff, (2003) find some short term effects, but they are very small.

Interestingly, this also points to a regularity noted in several of the survey papers: there is ample evidence that when managers think about "liquidity" they seem to be referring to breadth of ownership, and not bid-ask spreads, or total dollar volume of trade. 
More importantly for my investigation, the marketability hypothesis makes clear-cut predictions that are inconsistent with many of the patterns of constant nominal share prices. For example, why didn't share prices keep up with inflation? According to the marketability hypothesis, individuals have a budget constraint that restricts them to lower-priced shares. Suppose, for example, that an individual would like to diversify across ten stocks, and she has only $\$ 25,000$ to invest. If she allocates $\$ 2,500$ to each stock, and she is restricted to buying "round lots" (shares in multiples of 100$)$, she can pay no more than $\$ 25$ a share. This simple arithmetic ignores one important consideration: the investor who had $\$ 25,000$ to invest in 1933 is likely to have much more money (in nominal terms) today. It seems natural to assume that the budget constraint of the average individual investor should remain approximately constant in real dollars.

Assuming that the funds available for investing increase with inflation, then the marketability hypothesis clearly predicts that nominal share prices should keep up with inflation.

Otherwise, I am left with the incredible conclusion that the "preferred trading range" is set by some very impoverished and undesirable investor. Firms engage in odd-lot buyback programs specifically to eliminate these small investors, as the servicing costs of $\$ 19$ per shareholder per annum can be high when compared to the value held by a small shareholder (Frieswick, (2002)). Curiously, firms that have odd- 
lot buyback programs continue to split their shares, presumably making their shares attractive to the same class of small investors they intentionally bought out. For example, ESCO Technologies, (NYSE: ESE) held a voluntary buyback program for shareholders with fewer than 100 shares from March 3rd to April 3rd, 2003 when its stock was trading at approximately $\$ 34$, and subsequently did a 2:1 stock split on September 26th, 2005, reducing its stock price from approximately $\$ 100$ to $\$ 50$ per share.

We also note that many mutual funds have a minimum initial investment requirement, which is consistent with our claim that very small shareholders are not the preferred investors by most firms. The data refute what is arguably the most basic prediction of the marketability hypothesis.

The idea that stock splits are undertaken by firms to maintain a preferred trading range for retail investors is problematic for other reasons as well. First, many firms offer direct investment programs that allow investors to buy small quantities of shares without any commissions (Scholes and Wolfson (1989)). Second, over the past 20 years the pricing of retail brokerage has changed in a way that makes the marketability hypothesis untenable. Many brokerage firms charge a flat fee for trades up to 20,000 shares. This commission structure means that retail investors should have no preference about the number of shares that they trade. Also, while trading odd lots was difficult and expensive historically, in world of electronic trading this is 
no longer the case. ${ }^{18}$ So unless individual investors have specific preferences for lower priced stocks unrelated to their budget considerations, the marketability hypothesis is inconsistent with the facts. And if investors do have such preferences, why would their preferences for lower-priced stocks depend on the size of the company?

The marketability hypothesis also makes a clear prediction about diversified investment vehicles. In the mutual fund and exchange-traded fund settings, where a retail investor can obtain a well-diversified portfolio by purchasing one security, the marketability hypothesis predicts no splits at all. However, exchange-traded funds split their shares. For example, on April 24, 2006, the Rydex equal weight Standard \& Poor's index fund executed a 4:1 split, and on June 13, 2005, a dozen different iShares funds managed by Barclays Global Investors split either 2:1 or 3:1. In the case of open-end mutual funds, prediction is even more dramatic. The share price of such a fund is irrelevant, because you can purchase or sell whatever dollar value you want and the fund will calculate fractions of shares as necessary. And yet mutual funds do split. Moreover, I note that many mutual funds have a minimum initial investment requirement, which is consistent with my claims that very small shareholders are not

\footnotetext{
${ }^{18}$ In fact, there is some evidence that odd-lot trades get better execution on the New York Stock Exchange because of Rule 124, and the elimination of the odd-lot differential in 1991. Rule 124 effectively requires specialists to execute odd-lots at the same price as the most recent, or next, trade. An example of the benefits of odd-lot trading was highlighted in 2004 when the NYSE announced that it was imposing a censure and $\$ 50,000$ fine against Westminster Securities Corporation. The alleged abuse by Westminster was breaking up customer round-lot orders into odd- lot orders to sneak them ahead of other round-lot orders awaiting execution. The full text of Rule 124 is available at http://rules.nyse.com/NYSE/Help/Map/rules-sys186.html.
} 
the preferred investors by most firms, and mutual fund splits are hard to rationalize under the marketability hypothesis.

Finally, the marketability hypothesis suggests that share prices should respond to changes in the composition of stock owners-in particular, to the dramatic increase in institutional ownership that has occurred. According to the NYSE Factbook, the percent of corporate stocks that were directly owned by individuals declined from 90.2 percent in 1950, to 41.1 percent in 1998. At the same time, indirect holdings of corporate stocks, such as via mutual funds, have increased many-fold from 3.3 to 27.5 percent, and the fraction of stock owned by non-households, such as defined benefit pensions, has increased from 6.5 to 31.4 percent, as seen in the Federal Reserve Flow of Funds Accounts data. Non-retail trading in at least some securities accounted for 96 percent of New York Stock Exchange trading volume in 2002 (Jones and Lipson, 2003). In short, institutional holdings and trading dominate the market.

The major reduction in direct household holdings, and the corresponding increase in institutional holdings and trading, indicates that there has been a significant change in the characteristics of investors. Therefore, the marketability hypothesis would predict higher prices as this investor composition shift occurs, and firms cater to the new class of important investors. However, we already saw that share prices 
remained around $\$ 30$ throughout the entire period, despite the major changes in stock ownership.

The nominal share price puzzle could also be related to characteristics of the retail investor. ${ }^{19}$ For example, perhaps a few very wealthy individuals held stock in earlier periods, but now many more, though less-wealthy, individuals hold equity securities directly. The reduction in real price over time could then be a consequence of the fact that those less wealthy individuals are the marginal investors. However, the level of direct equity participation now and 80 years ago is quite similar. For example, the percentage of households with direct holdings of shares of stock in the 1920s was around 20 percent, roughly the same as in the late 1990s. As mutual funds have become increasingly popular since the mid-1960s, most individuals' stock-holdings are indirect, through these funds. Moreover, even nowadays stock ownership is highly concentrated: The wealthiest ten percent of the population in the United States owns 85.1 percent of common stock, and approximately one half of all households have zero stock holdings (Mishel, Bernstein, Allegretto (2005)). It seems unlikely that the nominal price stationarity can be attributed to changing characteristics of retail investors.

${ }^{19}$ I thank George Akerlof for his suggestion to investigate this point. 


\section{The Pay To Play Hypothesis}

A related hypothesis, which also posits an optimal trading range for stock prices, is based on the notion that firms set their share prices to induce brokers/dealers to provide liquidity through higher market-making profitability. Angel (1997) develops a theory of "relative tick size." In this approach, firms split their stock to lower the share price and increase the ratio of tick size (defined as the minimum possible difference between the bid and the ask price) to share price. A higher relative tick size economically motivates more dealers to make markets for the stock, and to provide more liquidity.

This theory is consistent with the pattern observed in the United States over the period 1930-1996 where both tick sizes and prices remained constant. However, the theory predicts that if tick sizes fall, prices should fall as well. A natural test is provided by the decimalization that occurred on the New York Stock Exchange. As Angel (1997, page 678) boldly stated: "[A] reduction in the minimum price variation from $\$ 0.125$ to $\$ 0.01$ could eventually lead to a reduction in the average share price by the same factor, 12.5, resulting in an average share price around $\$ 3 . "$ Starting in 1997, the natural experiment Angel hypothesized actually took place. The tick size on the NYSE changed from $1 / 8$ to $1 / 16$ and then to $1 / 100$. But Angel's prediction was not very successful. Rather than falling by a factor of 12.5 , share prices remained roughly constant during this period. Similarly, the reduction in minimum tick size on the 
Toronto stock exchange did not result in a like reduction in the average prices of shares traded on that exchange.

Another problem with this theory is that it is hard to see why large firms would feel any need to pay anyone to provide liquidity. Does the management at Microsoft or GE think that their shares would not trade if the price were $\$ 500$ or $\$ 1,000$ when Berkshire Hathaway, which has traded at over $\$ 100,000$ per share, is among the most consistently profitable stocks traded by specialist firm LaBranche? ${ }^{20}$ Even putting aside Berkshire Hathaway, Google's management seems to share my view that this argument is implausible since their share price has traded above $\$ 700$ and the firm appears to have no intention of splitting. Clayton Moran, an analyst with Stanford Group, remarked that "All the indications I get from the company is that they are comfortable with a stock price that implies a superiority to competitors so I don't think they are motivated to split the stock" (La Monica, 2006)

Finally, the tick size explanation can provide no explanation for mutual fund splits.

\footnotetext{
20 "As a rule, the spread on Berkshire A shares fluctuates between $\$ 100$ and $\$ 200$ a share. (On most other shares on the Big Board, the spread is a matter of pennies.) Like other chief executives, Mr. Buffett doesn't want to see big spreads between buyers and sellers of his stock. However, large spreads can be lucrative for specialist firms. "I want Berkshire to be a good stock for LaBranche, but not the best stock," says Mr. Buffett, referring to Mr. Maguire's employer, the specialist company LaBranche \& Co. Berkshire shares rank among LaBranche's most consistently profitable stocks, but not the most profitable, says owner Michael LaBranche" (Richardson, 2005).
} 


\section{The Signaling Hypothesis}

In a world of asymmetric information between those insiders who are managers and those outsiders who are investors, insiders may wish to convey their private information to the outsiders in the market, even if it is costly to do so. Several papers suggest that a stock split may serve as such a signaling device. As in all signaling models, two immediate questions arise: 1) What do the managers signal, and 2) What is the cost of the signal?

More generally, signaling theories propose explanations of puzzling behavior, such as investments in costly displays. The investment in a costly display can be supported under the following conditions. First, there must be a characteristic which is obscured by information asymmetry. Second, if this obscured characteristic were observable, the strategy of the players in the environment would be a function of this characteristic. Third, the costly display must be observable. Fourth, there must be a common set of beliefs between the displayers and the observers about the correlation of the costly display and the unobservable. Fifth, the display allows for at least a partially separating equilibrium, as the cost of the signal precludes a subset from imitating the signal. Finally, the cost of the signal (and the cost of falsely signaling) must be borne by the entity making the signal.

Biological sciences provide examples of certain costly exhibitions that distinguish certain individuals as being more desirable. Presumably, there are some 
differences between corporate and non-human signaling. However, I will use biological examples here as it allows me to build intuition and highlight certain important features without triggering the reader's desire to skip this section, as undoubtedly the reader is familiar with the economic signaling models, and needs no exposition from me to heighten her understanding.

Classic examples of biological signaling are often related to mating behavior. For example, in certain species of flies, longer eye stalks are correlated with more mating opportunities. ${ }^{21}$ For a signaling model to hold in this fly-mating setting, I can invoke the above listed conditions. First, the obscured characteristic is the probability of producing robust offspring, or the probability of successfully fulfilling the biological imperative. Robust offspring can be characterized by their ability to locate food, efficiently convert food into energy, mate successfully, and pass along "robust" genes. For simplicity, I assume that the robustness of the male is highly correlated with the probability of it producing robust offspring. Male robustness, however, is not observable: an observation of a male fly by a female fly would not fully reveal his robustness. Since the survival and mating success of offspring is a future event, and since flies presumably are not precognitive, I claim that robustness is an obscured characteristic. Second, female flies presumably would prefer to mate with the most robust males, so the mating strategy of the female flies presumably would be a

\footnotetext{
21 "stalk eyed flies have become canonical examples of the action of sexual selection and the evolution of male sexual traits (Wilkinson, 2001; Maynard Smith and Harper, 2004).." Pomiankowski et al. (2005), page 1166
} 
function of robustness, were it not obscured. Third, eye stalk length is clearly an observable characteristic, as the length of the eyestalk can exceed the insect's own body length. ${ }^{22}$ Fourth, it has been empirically demonstrated that females choose to mate with longer eye-stalked males, and males in the species make large investments in the growth of their eye stalks. While this is not conclusive proof that there is a shared belief between the males ("if I grow longer eye-stalks, females will know that I am robust") and the females ("males with longer eyestalks are more robust"), it is consistent with these shared beliefs. ${ }^{23}$ Finally, the eyestalks do provide for a partially separating equilibrium. Males with longer eyestalks are the preferred mates of females, and males grow the largest eyestalks that they can. Less robust males cannot invest in longer eyestalks, and have lower mating success.

The stalk-eyed fly example is intriguing as there is nothing special, ex ante, about the convergence on eye stalks as the signal. Longer eye stalks appear to have no benefit to the males of the species except in terms of mating selection. In fact, long eye stalks are quite costly to males: they reduce the field of binocular vision, and they restrict mobility in flight (Ribiak and Swallow 2007). Clearly, the signaling mechanism must be costly, otherwise it could be undertaken by low quality males, and therefore could not be a reliable signal. While the eyestalks do appear to be a reliable indicator

\footnotetext{
22 "In a number of stalk eyed fly species, female mate preferences have driven the evolution of exaggerated male eye stalks, which in extreme cases exceeds body length (Wilkinson and Reiollo, 1994; Wilkinson and Dodson, 1997; Hingle et al., 2001)" ).." Pomiankowski et al. (2005) page 1166

23 Using the term "beliefs" in this setting is a horrible abuse of the English language, but I request the reader's indulgence to allow consistency with game theory and microeconomic terminology.
} 
of robustness, there is no compelling reason that some other signal could have been used to convey the information about the male's robustness (Zimmer, 2008).

In non-human signaling, the equilibrium signal is generally the result of random mutations and convergence upon a norm. It is this "norm" characteristic that is often glossed over in the economic literature. Almost any costly investment in any meaningless display could serve as the signal. All the potential benefits of signaling can only be realized if there is a norm. This norm is the convergence of beliefs on the information context of a specific signal. This deserves special attention in the corporate finance setting.

Any odd behavior could be supported as a signal, which makes rejecting signaling stories difficult. However, if we believe that human managers have a greater ability to optimize than a fly, the signal should be efficient (i.e. the lowest cost mechanism which creates a separating equilibrium); if stock distributions are not the most efficient signaling mechanism, then these models are difficult to accept.

The biological cost of expending energy on specific characteristics which give no obvious benefits in terms of individual survival could be a second best outcome in terms of species survival if certain conditions are met. First, mating partners must hold a common belief that the observable result of having taken the costly action (in this case long eyestalks) is correlated with unobservable and desirable attributes. This norm correlation between an observable but unimportant characteristic and an 
unobservable but important characteristic is key to all signaling theories. Since any unimportant characteristic could act as the signal, convergence on a norm about which specific unimportant observable characteristic will be converged upon as the "key" characteristic for selecting an optimal mate is equally important.

If there is no convergence upon a single norm, the attempts at signaling are likely to have lower realized benefits. Assume that the female of the species has the ability to select her partner for mating purposes. Now consider that there are two types of females. The first female type believes that a display of colorful plumage (the observable but inherently unimportant characteristic) correlates with desirable characteristics. The second female type believes that a loud call correlates with desirable characteristics. For the males, there are two dimensions of characteristics. First the males can be of a "good" or "bad" type, where the good type and bad type are defined by inherently important, but unobservable characteristics. Second, males of the "good" type have the capacity to invest in either colorful plumage or in a loud call. Compare that setting to one in which the females of the species have coordinated onto a single norm where colorful plumage is desirable. No good type male would choose to invest in a loud call in this setting, thereby making a single signal environment more efficient. By extension, while the investment in colorful plumage is still costly, it is more likely to result in mating. Keeping this in mind we can now 
investigate signaling stories to identify what is the fixed cost, and whether this cost is borne exclusively by high-type firms.

Brennan and Copeland (1988) develop a model in which undervalued firms use stock splits to signal the quality and strength of their future prospects. In their model, splits are credible signals because they are costly. Since commissions are related to the number of shares traded, investors would save money by trading a smaller number of shares, each having a higher share price. Another component of the costs is the bidask spread. The relative bid-ask spread—defined as the bid-ask spread for $\$ 1$ worth of trade-is greater post-split, as my own tests and previous studies show (for example, Conroy, Harris, Benet, 1990). There are also administrative costs that add to the cost of the split, as mentioned earlier. In a signaling model, undervalued firms increase the number of shares and decrease share prices to signal their higher quality. ${ }^{24}$ In equilibrium, one might expect under-valued firms to end up with lower share prices than over-valued firms. The greater the split factor and the lower the price, the more credible the signal and the more likely the firm is under-valued. A final implication of the signaling hypothesis is that the market reaction to the split should be positive.

If stock splits are a rational economic signal, then they presumably should be correlated with future profitability. Lakonishok and Lev (1987) report that profitability

\footnotetext{
${ }^{24}$ Note that the signaling explanation is the opposite of the "pay to play" explanation: In the first, the split reduces liquidity and the costs are truly just burning money. In the second, the costs are effectively a payment for better liquidity and promotion. However both stories (and the entire literature related to splits) are premised upon the fact that costs of trade are increased by stock splits.
} 
does increase significantly, but it does so prior to the split rather than after the split. Asquith and Healy (1989) also find large earning increases, and returns, prior to a split, but none thereafter. Do splitting firms try to signal that they have already reached their peak and their growth rate should revert back to a lower level? That interpretation seems unlikely. The price of shares after stock splits seems less consistent with signaling than with "rejoining the herd" at the near-constant nominal stock price.

The evidence on price performance after splits is not uniform. In the seminal paper on this subject, Fama, Fisher, Jensen, and Roll (1969) found that firms having a stock split have experienced abnormal returns of 34 percent in the in the 30 months leading up to the split, but experience no abnormal returns thereafter. Byun and Rozeff (2003) find that any abnormal returns subsequent to a split are specific to the sample period chosen. Some studies do find abnormal returns over long horizons after splits, but such studies are very sensitive to the methods used, and there is no consensus on the results. ${ }^{25}$

The signaling model also predicts less information asymmetry after splits, since management's private information has already been conveyed to the market via the

25 For example, Grinblatt, Masulis, and Titman (1984) find median abnormal returns of 27 percent in the four months prior to the stock split, and 3 percent in the four months subsequent to the split. Desai and Jain (1997) find buy and hold abnormal returns of 7.05 percent in the year after the split, which suggests that the firm continues to have good performance post-split, and yet the signal is not fully incorporated into prices by the market. Ikenberry, Rankine, and Stice (1996) and Ikenberry and Sundaresh (2002) find abnormal returns of between 8 and 9 percent, and abnormally low negative earnings realization in the year subsequent to the split. 
split. This ought to lead to a reduction in "informed trades" following splits. Easley, O'Hara, and Saar (1998) examine this prediction and find no evidence that information asymmetry is reduced after splits.

Several of the facts I discussed earlier also seem at odds with the signaling hypothesis. Many exchange-traded funds are passive index funds, and it is very difficult to believe that they somehow have superior "inside information" that the underlying index they hold is going to outperform in subsequent periods--and yet they split. Mutual funds split, too, yet it is difficult to construct a model in which the funds can (much less do) predict out-performance. ADRs, or American Depository Receipts, are a financial vehicle that represents a certain number of shares of a foreign stock, but they are denominated in dollars and sold on U.S. stock exchanges. Unsponsored ADRs split, while their home country security, where most of the trades are done, does not (Muscarella and Vetsuypens, 1996). The depository bank that created the unsponsored ADR is unlikely to have better "inside information" on the future prospects of the firm than do the managers of the firm itself. From these examples, it seems difficult to identify exactly what splits signal.

Signaling theories also imply that as the cost of the signal changes, the intensity of the signal should change as well. Thus when brokerage commissions dramatically decreased with the shift from fixed minimum to negotiated commission on "Mayday" in May, 1975 and again with the penetration of discount brokers, we should have 
observed a like decline in share price. Similarly, the reduction in the minimum bid-ask over a very brief period in time should have an abrupt impact on share prices, which it has not. From 1933 to 1997 the minimum tick size remained constant at $1 / 8$ of a nominal dollar, June 23, 1997 marked the first change in nominal tick size from 1/8 to 1/16, and January 29, 2001 marked the NYSE's transition to having all stocks quoted in decimals, and yet throughout these changes, prices have remained remarkably constant. In summary, the evidence casts doubt that signaling could explain share prices remaining at a nominal price of $\$ 30$ since the Great Depression.

Finally, there are some questions that always arise with signaling hypotheses. Firms that split their shares are primarily those whose shares have greatly increased in price. Why is this signal more likely to be available in bull markets or for firms that have been doing exceptionally well? Wouldn't firms in down markets (or firms that have done poorly in the recent past) also have private information they would like to signal? In fact, why don't low price firms use splits to signal strong future prospects, since a split to an abnormally low price would seem to be an especially strong signal? Finally, why does every high priced company undertake this specific signal? Does every high priced firm have good future prospects, except for Berkshire Hathaway and Google? 


\section{Customs and Norms}

As Sherlock Holmes liked to say, "When you have eliminated the impossible, whatever remains, however improbable, must be the truth." The standard economic explanations for stock splits cannot account for the facts surrounding the nominal share price puzzle, so I must consider alternatives. I consider the possibility that firms are simply following convention when they set the share price. They set the price to whatever is considered the norm. Unlike the norm of driving on either the left- or right-hand side of the road, in this case there is no strong penalty for violating the norm. Having an outlier price such as Berkshire Hathaway or Google will not get you killed. However, the norm is sufficiently engrained that going against it invites scrutiny. Almost every in-depth article in the popular press on Berkshire Hathaway comments on its unusually high per share price, and on Warren Buffet's unwillingness to split the stock.

Interestingly, the norm of an average price of about $\$ 30-\$ 40$ has been formed only since the 1929 crash. Figure 9 shows that until the crash in 1929 stock prices were much higher. Prior to 1915 share prices were quoted as a percentage of their par value, not in dollars (Angel, 1997), and it was very common for par values to be set at $\$ 100$ a share. Recall the earlier quote from Whittaker (1929): "If shares that have a high market value (for example, \$500) are brought by a sufficiently large stock dividend to an ordinary level (perhaps $\$ 100$ ), the price is said to be brought within the 
trading range." (pg. 33) This comment again highlights the pervasive belief that there is an "ordinary" level for prices, which is consistent with my norms premise: there was a convention of stock prices being approximately $\$ 100 /$ share prior to the great depression, and stock splits targeted this conventional price. 


\section{Figure 9: Nominal Equal Weighted Average Price per Share of Securities Listed on the NYSE and AMEX, 1815 to $2007^{26}$}

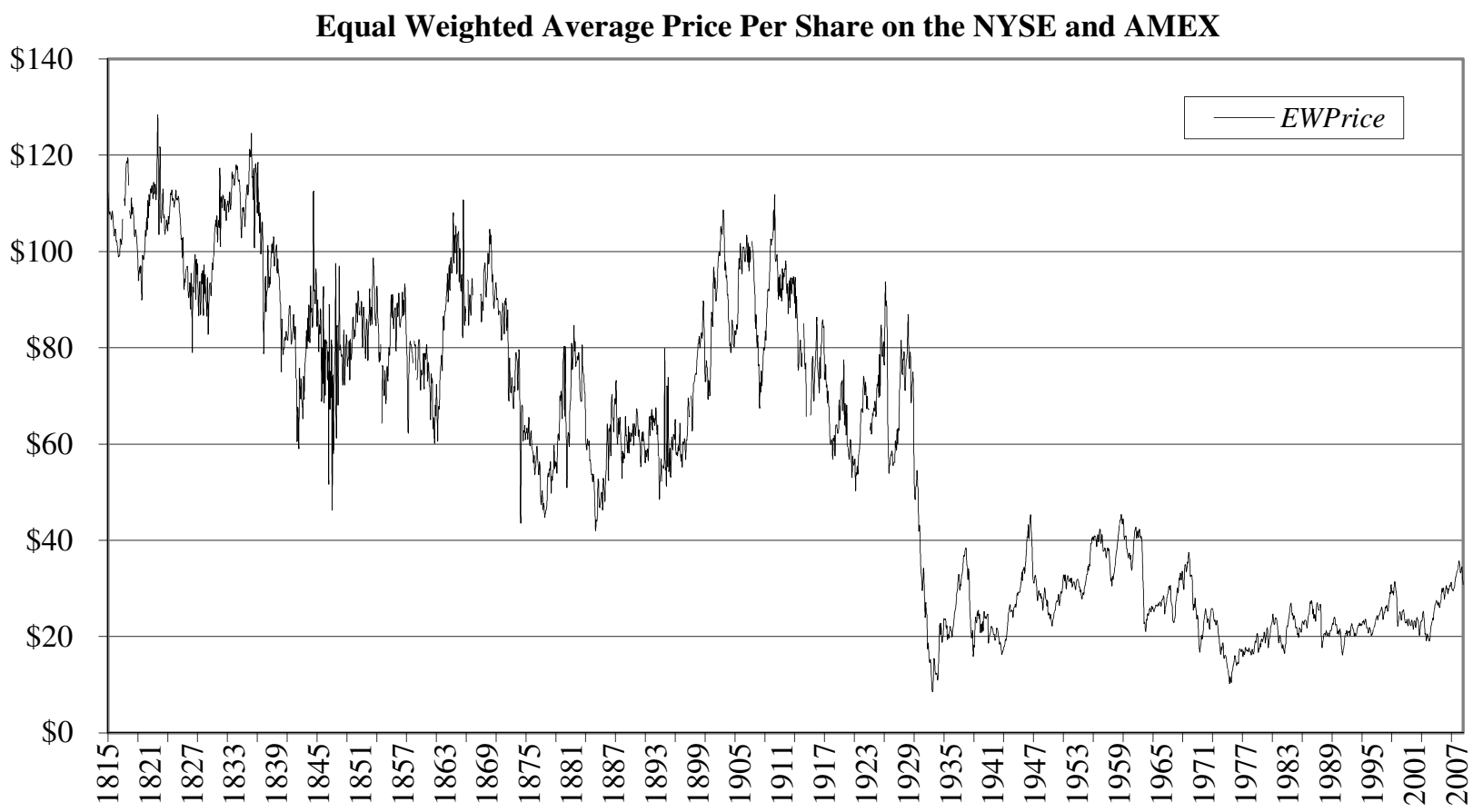

${ }^{26}$ Data for January 1815 to December 1925 is from the "NYSE Monthly Price File from 1815 to 1925," made available from the NYSE History Research Project by the International Center of Finance, Yale University. The data for January 1926 to the present is from the Center for Research in Security Prices (CRSP). 
However, after the market crash of 1929 share prices dropped from roughly $\$ 70$ to $\$ 30$ and have never increased. This pattern suggests that the norm around share prices can be changed in response to a dramatic shock. Additional anecdotal evidence from Europe around the introduction of the euro currency suggests that price norms can be broken when the set of "peer" firms change. After the introduction of the euro, for example, many Italian-listed companies reportedly considered reverse stock splits to raise their trading prices to more "respectable" levels (Bologna, 1999).

Admittedly, because no formal model exists of how norms are created and maintained, it is difficult to test the norms hypothesis. At this stage, I can conjecture about the process of the formation of the "price-range norm." Perhaps $\$ 30 /$ share was a binding constraint for investors in the 1930s. The average annual income in the 1930 s in the United States was under $\$ 1,400$, making a $\$ 30$ purchase a meaningful amount of money. With this in mind, the findings of Dooley (1930) are plausible - a lower price allowed investors to purchase shares of the companies, and therefore increased the breadth of share ownership. For example, a May 17, 1916, article in the New York Times reported that the Willys-Overland Company (automotive) split its shares 4:1, moving its price from approximately $\$ 225 /$ share to $\$ 56$. Anticipation of the increased participation by a broader set of investors precipitated by the split had led to almost a 15 percent increase in price. However, by 2004 the mean annual 
income in the United States exceeded $\$ 60,000$. This dramatic increase in nominal income, by over 40 times, makes $\$ 30 /$ share seem no longer relevant as a binding constraint. In other words, the $\$ 30$ share price is a vestigial norm.

If investors used price information for classifying firms (perhaps because of information costs or bounded rationality), it made sense for firms to coordinate on price. Once established, the norm for firms to split their stocks when the per-share price has gotten high became self-reinforcing. When considered in the time series, each of the explanations for why a particular share price might have been optimal at one point in time also leads to the conclusion that $\$ 30 /$ share could not have been optimal in 1930, 2007, and every date in between. However, the active targeting of a price of $\$ 30 /$ share persisted throughout this time series.

Regardless as to what mechanism was initially responsible, once the behavior became a norm, it became self-reinforcing. In fact, there is some limited direct evidence supporting this idea. Barker (1956) states, "As it is, the large majority of split stocks end up in the $\$ 20$ to $\$ 50$ price range, simply because this is commonly thought by most executives and financial counselors to be the most popular one with investors" (page 105, my emphasis). While it is unlikely that any manager would admit to arbitrarily selecting the target stock price, it does seem reasonable that, in the face of contradictory evidence about why firms perform stock splits and what the benefits of a split, if any, may be, conventional wisdom or a heuristic could be used to make the choice. 
Selecting a price which appears to be popular with investors is identical to selecting one which matches the level of previous splits by peer firms. Furthermore, matching peer firm prices is consistent with following a norm, particularly when there is no theory which can support the same price as being optimal for over 70 years!

Furthermore, Eismann and Moses (1978) and Baker and Phillips (1993) report the single most frequent explanation cited as to why companies issued stock dividends was "Historical Company Practice." They conclude “... managers may have read and understood the literature ${ }^{27}$, but still feel apprehensive about stockholder reaction to a change in the company's historical stock dividend practice." (pg.80) That managers would continue to take an action merely because it was done before, and that changing from the historic precedent would potentially cause alarm, is exactly what a model of norms would predict.

As my discussion has suggested in a number of places, the norm is not quite as simple as " $\$ 30$ a share." Instead, the norm for the stock price of U.S. firms appears to depend on the firm's characteristics, such as size and industry. Managers appear to choose stock splits in an attempt to bring share price back in line with that of their size and industry peers. In Table 7, I report that over 62 percent of the variance in post-split prices can be explained by a model that predicts the split-targeted price by a firm's share price deviation from its size and industry peers. When I restrict the

\footnotetext{
${ }^{27}$ The authors are referring to the literature on stock distributions, which, as they state in the article introduction "frequently assert that shareholders get no genuine benefit from either the payment of stock dividends or the issuance of stock splits" pg 77
} 
sample to "large" splits, defined as $1.25: 1$ or greater (which eliminates from the sample firms that have a policy of small annual dividends paid in the form of stock that otherwise the data may count as "splits"), I have even stronger results, with an Rsquare of over 78 percent. This result supports the idea that firms are reluctant to deviate from the norm, and when they find themselves violating the pricing norm, they split to a price that rectifies the violation. My findings are consistent with other empirical work as well. Lakonishok and Lev (1987) report that post-split share prices converge to the industry norm. Similarly, McNichols and Dravid (1990) show that the further away the share prices are from the norm price, the higher the split factor. (See also Dyl and Elliott (2006)). 


\section{Table 7: The Price Targeted by Mangers via Stock Splits ${ }^{28}$}

\section{Panel A: All Forward Splits}

\begin{tabular}{|c|c|c|c|c|}
\hline \multicolumn{5}{|c|}{$\begin{array}{c}\text { Adj. } R^{2}=0.6284 \\
N=16092\end{array}$} \\
\hline & Parameter & & & \\
\hline Variable & Estimate & Standard Error & t-value & $\mathbf{P}$ \\
\hline $\begin{array}{r}\text { Intercept } \\
\text { (Pre-Split Price)- }\end{array}$ & 2.65406 & 0.12688 & 20.92 & $<0.0001$ \\
\hline $\begin{array}{l}\text { (Size Median Price) } \\
\text { (Pre-Split Price)- }\end{array}$ & 0.34356 & 0.1080 & 31.82 & $<0.0001$ \\
\hline (FF48 Industry Median Price) & 0.24427 & 0.00945 & 25.85 & $<0.0001$ \\
\hline
\end{tabular}

\section{Panel B: Average All Splits greater than or equal to 1.25:1}

Adj. $\mathbf{R}^{2}=\mathbf{0 . 7 8 5 1}$

\begin{tabular}{|c|c|c|c|c|}
\hline \multicolumn{5}{|c|}{$\mathrm{N}=8370$} \\
\hline & Parameter & & & \\
\hline Variable & Estimate & Standard Error & t-value & $\mathbf{P}$ \\
\hline $\begin{array}{r}\text { Intercept } \\
\text { (Pre-Split Price)- }\end{array}$ & 3.00831 & 0.18731 & 16.06 & $<0.0001$ \\
\hline $\begin{array}{l}\text { (Size Median Price) } \\
\text { (Pre-Split Price)- }\end{array}$ & 0.45406 & 0.01328 & 34.19 & $<0.0001$ \\
\hline (FF48 Industry Median Price) & 0.27384 & 0.01198 & 22.85 & $<0.0001$ \\
\hline
\end{tabular}

\footnotetext{
${ }^{28}$ Data is from CRSP as previously described. I determine for each firm the month end price prior to the month in which it announces its split (Pre-Split Price), the price at month end of the split announcement ("Post-Split Price"), the median price of its size peers (as determined by size deciles) at the end of the year prior to the split announcement, ("Size Median Price"), and the median price of its industry peers (as determined by the Fama French 48 industry definitions) at the end of the year prior to the split announcement (FF48 Industry Median Price"). Panel A shows the regression results from all firms from 1933 through 2005 that had a forward split, and Panel B shows the results for all firms from 1933 through 2005 that had a 1.25:1 or greater split. The regression model is
}

$$
\begin{aligned}
{[(\text { Pre }- \text { Split Price })-(\text { Post }- \text { SplitPrice })] } & =\alpha+\beta_{1}[(\text { Pre }- \text { Split Price })-(\text { Size Median Price })]+ \\
+ & \beta_{2}[(\text { Pre }- \text { Split Price })-(\text { FF48 Industry Median Price })]+\varepsilon
\end{aligned}
$$


The norm applies to foreign firms listed on US exchanges as well. For example, Muscarella and Vetsuypens (1996) note a consistency in the pricing of American Depository Receipts or ADRs_-which, as described earlier, are securities representing a certain number of shares of foreign stock that are denominated in dollars and sold on U.S. stock exchanges. The share price on the home exchange is in line with that exchange's pricing, and the number of shares packaged in an ADR brings its price in line with other securities on the foreign exchange. Share splits keep the prices at the appropriate norms. I also find evidence that Global Depository Receipts (“GDRs”), a similar type of security traded on the London exchange, are packaged at ratios which decrease the cross sectional variability of prices of the GDRs relative to the prices of the underlying securities.

An interesting question is whether firms suffer economically by violating the norm. To investigate this question, I compare the returns of firms with high prices to firms with norm prices. Specifically, I run the following cross-sectional regression each year (from 1962 through 2005). $p_{i}=\alpha+\sum_{j=1}^{5} d_{j}$ Size $_{j}+\sum_{k=1}^{48} d_{k}$ Industry $_{k}+e_{i}$ Where $\mathrm{p}_{\mathrm{i}}$ is the firm's average annual price, Size is a dummy variable for 5 size quintiles, and Industry is a dummy for 48 industry categories provided by Eugene Fama and Kenneth French..

I use the error term from the regression to rank order firms in terms of their deviation from the norm: I then use these ranks to assign firms into deciles, and call 
the firms in the tenth decile (firms with the highest prices relative to their peers) "Norm Violators" and firms in the $5^{\text {th }}$ and $6^{\text {th }}$ deciles "Norm Adherents". Every year I match each "Norm Violator" firm to a set of firms from the "Norm Adherent" group which are in the same book-to-market and size quintile. I then calculate the average return of the "Norm Violator" portfolio, and subtract the average return of the "Norm Adherent" portfolio of matched firms for each year. I then use the time series average of the difference in portfolio returns, and their standard deviation to calculate the difference in returns for firms that violate price norms, as opposed to those firms that adhere to the price norm. I find that the violators actually earn a tiny (and insignificant) 7.34 basis points per year more than the firms that adhere to the norm.

Based on this analysis, it appears that firms that violate the price norm do not generate any economically or statistically significantly different returns over the next year. This suggests that the failure to split is not punished in any way, and that the aggregate effects of adhering to the norm compared to violating the norm are not material. (Warren Buffett can relax-he has been right all along.) This is further evidence that the mechanism that generates the price stationarity is norms, and not some economic rationale. It also suggests that while firms may try to cater to investor preferences via price targeting actions as suggested by Greenwood et al, 2008, the gains from catering are short lived and reversed over time. 


\section{Conclusion}

U.S. share prices have remained constant at around $\$ 30$ in nominal terms since the Great Depression, while the general price level in the U.S. economy have risen more than tenfold. These constant share prices are not a coincidence, but rather result from a pro-active effort of firms splitting their stock. This pattern cannot be explained by the standard explanations for stock splits, such as marketability and investor budget constraints, by "pay to play" considerations such as bid-ask spread and brokerage commissions, nor by signaling. The average price choice of firms and mutual funds in the United States has remained stable in the face of changing tic size, investor composition, trading costs, inflation, real wealth, and market returns. I conclude that the constant nominal share prices are a puzzle when viewed through the conventional lenses.

In my view, firms are following norms when they determine their "optimal" trading range. Specifically, keeping share prices in the same range for 70 years is the result of firms following traditions and norms that have evolved over time. Why have prices in the US remained at $\$ 30$ for so long? I respond in the same manner as Tevya, the central character in Fiddler on the Roof. When asked why things were done as they had always been done, he replied that he had a simple explanation: "And what is that you may ask? I can tell you that in one word. 'Tradition!”' 
Tradition may also explain other aspects of corporate behavior (Akerlof (2007), Cronqvist et al. (2006), Ben-David, Graham, and Harvey (2006)). For example: Why do some firms have almost no debt? When and why do firms initiate dividend payments (which are also irrelevant in a Miller and Modigliani (1961) world)? Why are some firms sensitive to cash flows while others are not? (Kaplan and Zingales (1997, 2000)) Why do spin-offs behave like their parents? (Cronqvist et al (2006)).

I have illustrated some of the empirical regularities that make constant nominal prices a puzzle, but I think that the role of norms has been under-appreciated in the literature in general. Why do bonds have a face value of $\$ 1,000$ ? Why have the regulations surrounding "accredited investor" status remained constant for so many years? While some of these examples are relatively trivial, others may provide more substantial insights into the capital markets. Norms provide a parsimonious explanation for all these phenomena: This is the way things have always been done. 


\section{BIBLIOGRAPHY}

Akerlof, G. A., 2007, The Missing Motivation in Macroeconomics, American Economic Association Presidential Address.

Angel, J., 1997, Tick Size, Share Prices, and Stock Splits, Journal of Finance 52, 655-681.

Asquith, P., P. Healy, and K. Palepu, 1989, Earnings and Stock Splits, The Accounting Review 64, 387-403.

Baker, H., and P.L. Gallagher, 1980, Management's View of Stock Splits, Financial Management 9, 73-77.

Baker, H. Kent and Aaron L. Phillips, 1993, Why Companies Issue Stock Dividends, Financial Practice and Education 3, 29-38.

Baker, H., and G. Powell, 1993, Further Evidence on Managerial Motives for Stock Splits, Quarterly Journal of Business and Economics 32, 21-31.

Bar-Josef, S and L. Brown, 1977, A Re-Examination of Stock Splits Using Moving Betas, Journal of Finance 32, 1069-80.

Barker, C. A., 1956, Effective Stock Splits, Harvard Business Review 34 (JanuaryFebruary, 1956), 101-106. 
Ben-David, Itzhak, John R. Graham, and Campbell R. Harvey, 2006, Managerial Overconfidence and Corporate Policies, Working Paper

Bertrand M., A. Schoar, 2003, Managing with Style: The Effect of Managers on Firm Policies, Quarterly Journal of Economics 118(4), 1169-1208.

Berle, Adolf A., and Means, Gardiner C., 1932, The Modern Corporation and Private Property. New York: Macmillan Publishing Co.

Bologna, Stephanie Apap, 1999, Single Currency Creates New Penny Stocks, but Do They Have Value? : In Italy, Euro Means More and Less, International Herald Tribune, January 16

Brennan, M., and T. Copeland, 1988a, Stock Splits, Stock Prices and Transaction Costs, Journal of Financial Economics 22, 83-101.

Brennan, M., and T. Copeland, 1988b, Beta Changes Around Stock Splits: A note, Journal of Finance 42, 1009-1013.

Brennan, M. and P. Hughes, 1991, Stock Prices and the Supply of Information, Journal of Finance 46, 1665-1691.

Byun, J. and M.S. Rozeff, 2003, Long-run Performance after Stock Splits: 1927 to 1996, Journal of Finance 58, 1540-6261. 
Conroy, R., R. Harris, and B. Benet, 1990, The Effects of Stock Splits on Bid-Ask Spread, Journal of Finance 45, 1285-1295.

Copeland, T., 1979, Liquidity Changes Following Stock Splits, Joumal of Finance 37, $115-42$.

Cronqvist, H., A. Low, M. Nilsson, 2006, Does Corporate Culture Matter for Firm Policies?, Working Paper.

Desai, Hemang, Prem C. Jain, 1997. Long-Run Common Stock Returns following Stock Splits and Reverse Splits, Journal of Business 70(3), 409-33.

Dolley, J., 1933, Common Stock Split-Ups, Motives and Effects, Harvard Business Review 12, 70-81.

Dyl E., W.B. Elliott, 2006, The Share Price Puzzle, Journal of Business 75.

Easley, D., M. O'Hara, and G. Saar, 1998, How Stock Splits Affect Trading: A Microstructure Approach, Journal of Financial and Quantitative Analysis 36, 25-51.

Eisemann, Peter C. and Edward A. Moses, 1978, Stock Dividends: Management's View, Financial Analysts Journal 34(4) (Jul. - Aug., 1978), 77-80.

Fama, E., L. Fisher, M. Jensen, and R. Roll, 1969, The Adjustment of Stock Prices to New Information, International Economic Review 10, 1-21. 
Fama, Eugene and Kenneth MacBeth, 1973, Risk, return, and equilibrium: Empirical tests, Journal of Political Economy 81, 607-636

Fernando, C., S. Krishnamurthy and P. Spindt, 1999, Is Share Price Related to Marketability? Evidence from Open-end Mutual Fund Share Splits, Financial Management 28(3), 15-31.

Fernando, C., S. Krishnamurthy and P. Spindt, 2004, Are Share Price Levels Informative? Evidence from the Ownership, Pricing, Turnover, and Performance of IPO Firms, Journal of Financial Markets 7, 377-403

Gompers, Paul, Josh Lerner, 2003. "The Really Long-Run Performance of Initial Public Offerings: The Pre-Nasdaq Evidence," Journal of Finance 58(4), 1355-1392.

Greenwood, Robin, 2009. "Trading Restrictions and Stock Prices," Review of Financial Studies 22(2), 509-539.

Grinblatt, M., R. Masulis, and S. Titman, 1984, The Valuation Effects of Stock Splits and Stock Dividends, Journal of Financial Economics 13, 461-490.

Hasbrouck, Joel, August, 2006, .Trading Costs and Returns for US Equities: The Evidence from Daily Data. NYU Stern School Department of Finance Working Paper. 
Ikenberry, D., Ramnath, S. 2002, Underreaction to Self-selected News Events: The Case of Stock Splits, Review of Financial Studies 15, 489-526.

Ikenberry, D., G. Rankine, and E Stice, 1996, What Do Stock Splits Really Signal?, Journal of Financial and Quantitative Analysis 31, 357-375.

Kadapakkam, P., S. Krishnamurthy, and T. Yiuman, 2005, Stock Splits, Broker Promotion, and Decimalization, Journal of Financial and Quantitative Analysis 40(4), 873895.

Kaplan, Steven N., and Luigi Zingales, 1997, Do financing constraints explain why investment is correlated with cash flow?, Quarterly Journal of Economics 112, 169-215.

Kaplan, Steven N., and Luigi Zingales, 2000, Investment-cash flow sensitivities are not valid measures of financing constraints, Quarterly Journal of Economics 115(2), 707712.

Lakonishok, J., and B. Lev, 1987, Stock Splits and Stock Dividends: Why, Who and When, Journal of Finance 42, 913-932.

Lamoureux, C., and P. Poon, 1987, The Market Reaction to Stock Splits, Journal of Finance 42, 1347-1370. 
McNichols, M. and A. Dravid, 1990, Stock Dividends, Stock Splits, and Signaling, Journal of Finance 45, 857-879.

MacKinlay, A.C., 1997, Event Studies in Economics and Finance, Journal of Economic Literature 35, 13-39.

Means, Gardiner C., 1930, The Diffusion of Stock Ownership in the United States, Quarterly Journal of Economics 44, 561-600.

Merton, R. 1987, A Simple Model of Capital Market Equilibrium with Incomplete Information, The Journal of Finance 42(3), 483-510.

Miller, M., 1977, Debt and Taxes, Journal of Finance 32, 261-275.

Mishel, Lawrence, Jared Bernstein, and John Schmidt, The State of Working America, 1998-1999, An Economic Policy Institute Book, Ithaca, N.Y.: ILR Press, an imprint of Cornell University Press, 1998.

Mishel, Lawrence, Jared Bernstein, and Sylvia Allegretto, The State of Working America, 2004/2005, An Economic Policy Institute Book. Ithaca, N.Y.: ILR Press, an imprint of Cornell University Press, 2005.

Monograph No. 29, The Distribution Of Ownership in the 200 Largest Nonfinancial Corporations, Investigation of Concentration of Economic Power, Temporary 
National Economic Committee United States Government Printing Office, Washington 1940.

Muscarella, C, and M. Vetsuypens, 1996, Stock Splits: Signaling or Liquidity? The Case of ADR 'Solo splits', Journal of Financial Economics 42, 3-26.

Nayak, S. and Prabhala, N. 2001, Disentangling the Dividend. Information in Splits: A Decomposition Using Conditional Event-Study Methods, Review of Financial Studies $14,1083-1116$.

Odean, T., B. Barber, 2001, Boys will be Boys: Gender, Overconfidence, and Common Stock Investment, Quarterly Journal of Economics 116, 261-292.

Ohlson, J., and S. Penman, 1985, Volatility Increases Subsequent to Stock Splits, Journal of Financial Economics 14, 251-266.

Pomiankowski, Andrew , Matthew Deniff, Kevin Fowler, and Tracey Chapman, 2005, The Costs and Benefits of High Early Meeting Rates in Male Stalk Eyed Flies Cyrtodiopsis Dalmanni,:Journal of Insect Physiology 51(10). 1165-1171.

Powell, G., and J. Baker, 1996, The Effect of Stock Split on the Ownership Mix of a Firm, Review of Financial Economics 3, 70-88. 
Ribak G, Swallow JG., 2007, Free Flight Maneuvers of Stalk-eyed Flies: Do Eye-stalks affect Aerial Turning Behavior. Journal of Comparative Physiology A: Neuroethology, Sensory, Neural, and Behavioral Physiology 193(10), 1065-79.

Richardson, Karen, 2005, Mr. Maguire Trades One Stock All Day Long; A Throwback to a Bygone Era, Berkshire Hathaway 'Specialist' Is In Charge of Only Those Shares. Wall Street Journal.(Eastern edition). Nov 12, 2005, pg. B.1.

Ryser, J., 1996, Split Opinions, CFO magazine, September 1996, 82-85.

Rozeff, M, 1998, Stock Splits: Evidence from Mutual Funds, Journal of Finance 53, 335349.

Schulz, Paul, 1999, Stock Splits, Tick Size, and Sponsorship, Journal of Finance 55(1), $429-450$.

Sosnick, Stephen H., 1961, Stock Dividends are Lemons, not Melons, California Management Review 3(2), 61-82.

Turton, D., 2004, Lip-Plates and the people who take photographs, Anthropology Today 20(2), 3-8.

Warshow, H. T., 1924, The Distribution of Corporate Ownership in the United States, Quarterly Journal of Economics 39, 15-38. 
Whitaker, A. C., 1929, The Stock Dividend Question, The American Economic Review 19(1), 20-42.

Zimmer, Carl, 2008, The Evolution of Extraordinary Eyes: The Cases of Flatfishes and Stalk-eyed Flies. Evolution Education \& Outreach 1 (4), 487-492. 